Universidade de Brasília

Instituto de Letras - IL

Departamento de Linguística, Português e Línguas Clássicas - LIP

Programa de Pós-Graduação em Linguística - PPGL

\title{
Sobre as orações gerundivas com sujeito oracional no português do Brasil
}

Dissertação de mestrado em linguística

\author{
Camila Parca Guaritá
}

Brasília

Fevereiro, 2015 
Universidade de Brasília

Instituto de Letras - IL

Departamento de Linguística, Português e Línguas Clássicas - LIP

Programa de Pós-Graduação em Linguística - PPGL

\title{
Sobre orações gerundivas em português brasileiro
}

\author{
Camila Parca Guaritá \\ Orientadora: Eloisa Nascimento Silva Pilati
}

Dissertação apresentada ao Departamento de

Linguística, Português e Línguas Clássicas da Universidade de Brasília como requisito para a obtenção do grau de Mestre em Linguística.

Brasília

Fevereiro, 2015 
Dedico esta dissertação a minha maravilhosa mãe, mesmo quando poucos acreditaram em mim ela me defendeu e apoiou. Obrigada. 
Agradecimentos

à $\operatorname{Prof}^{\mathrm{a}} \operatorname{Dr}^{\mathrm{a}}$ Eloisa Nascimento Silva Pilati, pela orientação, paciência e pelo constante apoio; aos meus queridos pais, pelo carinho e por serem meu porto seguro, sempre ao meu lado em qualquer situação;

aos meus irmãos, Lucas e Paula, pelo companheirismo e amor incondicionais;

aos professores queridos que tive na Universidade de Brasília, pelo conhecimento passado; aos colegas de mestrado, em especial à Juliana, Manuela e ao Jonathan, pelas melhores conversas acadêmicas;

ao meu avô pelas discussões diárias que tanto me ensinaram. 


\section{RESUMO}

Esta dissertação investiga as propriedades sintáticas e semânticas de orações reduzidas de gerúndio em que o referente do verbo no gerúndio é toda a informação contida na oração principal. Dois fatores principais motivaram a realização da pesquisa: a) não há descrições nas gramáticas tradicionais brasileiras sobre a existência de orações gerundivas com sujeito oracional (cf. Cunha \& Cintra (2008) e Castilho (2010); b) não há consenso nas análises de cunho gerativistas que investigaram as orações gerundivas em português Moutella (1995), Lopes (2004), Móia \& Viotti (2004) e Lobo (2001, 2003, 2009). Moutella (1995), por exemplo, ao analisar orações como $O$ avião caiu, matando 150 pessoas, levanta a possibilidade de tal oração ser do tipo coordenada. Já Lopes (2004) analisa as orações gerundivas com sujeito oracional, tais como $O$ avião caiu, deixando vários feridos, e as classifica como orações relativas apositivas de foco. Análises sobre a tipologia das orações gerundivas, como as de Lobo (2001, 2003 e 2009) e Móia \& Viotti (2005), não incluem as orações gerundivas com sujeito oracional, fato que revela haver uma lacuna nos estudos linguísticos em relação a esse tipo de oração. A hipótese defendida nesta pesquisa é a de que as orações gerundivas com sujeito oracional, tais como Segundo a lei, nos últimos dois anos o indice foi reduzido para zero, tornando a lei mais eficaz, são orações cujas características sintáticas e semânticas são comparáveis às orações relativas livres (cf. Móia 1992), iniciadas por o que. 


\section{ABSTRACT}

In this study, we investigate de syntactic and the semantic properties of the gerundive sentences in which the reference of the gerund verb in the embedded clause is the role information presented in the matrix clause. Two factors were motivational for this research: a) there are no descriptions in Brazilian traditional grammars about the gerundive sentences with a clausal subject (cf. Cunha \& Cintra (2008) e Castilho (2010)); b) there is no consensus about the classification of the gerundive sentences in portuguese (cf. Moutella (1995), Lopes (2004), Lobo (2001, 2003, 2009), Móia \& Viotti (2004)). Moutella (1995) shows the example $O$ avião caiu, matando 150 pessoas, and consider it as a coordinate sentence; Lopes (2004) analyses the gerundive sentences with a clausal subject, such as $O$ avião caiu, deixando vários feridos, as relative appositive of focus; Lobo (2001, 2003, 2009) and Móia \& Viotti (2004) analyze the gerundive sentences in European Portuguese, their work apparently don't include the gerundive sentences with a clausal subject. The hypothesis defended in this research is that de gerundive sentences with a clausal subject such as Segundo a lei, nos últimos dois anos o indice foi reduzido para zero, tornando a lei mais eficaz are sentences in which the syntactic and semantic features are similar to the "relativas livres", the relative sentences with the subject non specified (cf. Móia 1992) started with o que. 


\section{Sumário}

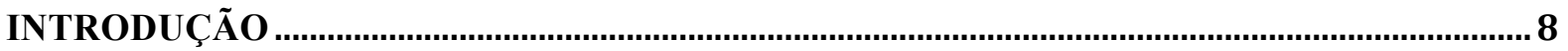

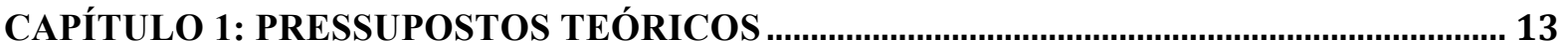

CAPÍTULO 2: QUADRO TEÓRICO SOBRE GERUNDIVAS: CONTEXTUALIZAÇÃO..... 18

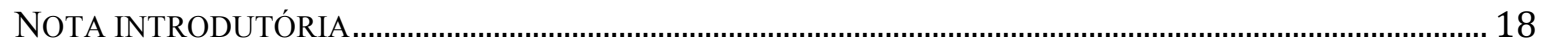

2.1 MOUTELLA (1995): CARACTERIZAÇÃO SINTÁTICA DE ORAÇÕES GERUNDIVAS EM PORTUGUÊS BRASILEIRO.

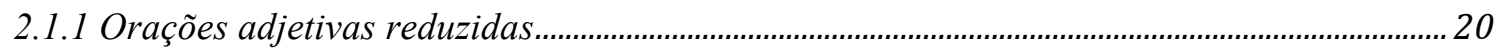

2.1.2 Orações subordinadas substantivas reduzidas: um caso não descrito pelas gramáticas

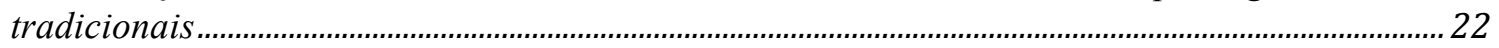

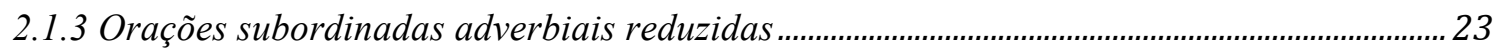

2.1.4 Orações gerundivas com sujeito oracional .................................................................................24

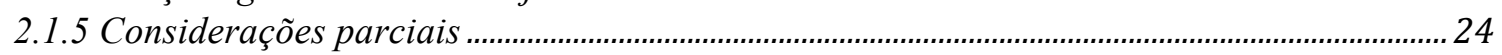

2.2 LOBO (2001, 2003 E 2009): CLASSIFICAÇÃO DAS ORAÇÕES GERUNDIVAS EM PORTUGUÊS

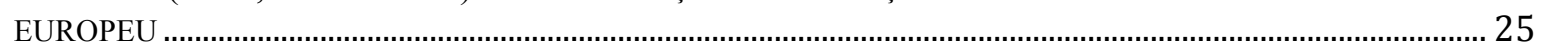

2.2.1 Lobo 2001: gerundivas predicativas e gerundivas adjuntas ....................................................2.

2.2.2 Lobo (2003): Orações gerundivas integradas e periféricas .......................................................2

2.2.3. Lobo (2009): Orações gerundivas predicativas e adjuntas: quadros explicativos ...............31

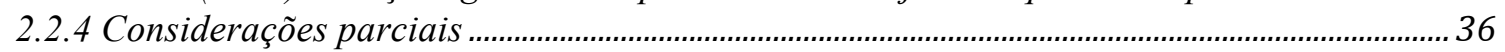

2.3 MÓIA \& VIOTTI (2004): DESCRIÇÃO DE INTERPRETAÇÕES SEMÂNTICA DO GERÚNDIO ................. 36

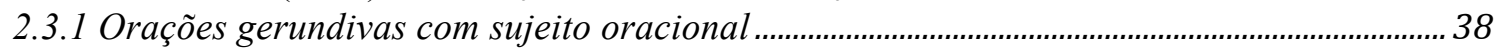

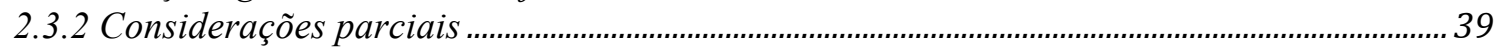

2.4 RODRIGUES $(2007,2010)$ : ORAÇÕES GERUNDIVAS EM POSIÇÃO ARGUMENTAL............................. 39

2.4.1 Rodrigues (2007): Orações gerundivas como complementos de verbos de percepção ........ 39

2.4.2 Rodrigues (2010): orações gerundivas como complemento de verbos volitivos ..................... 41

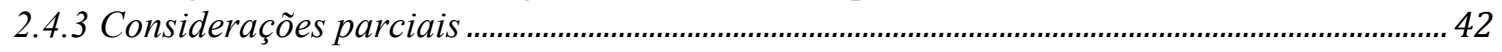

2.5 LOPES (2004): ANÁLISE DAS ORAÇÕES APOSITIVAS DE FOCO ........................................................... 42

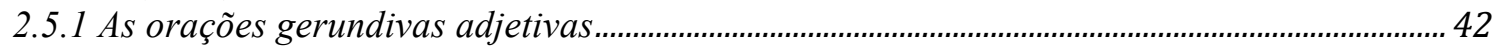

2.52 Orações gerundivas com sujeito oracional: as orações apositivas de foco ............................. 43

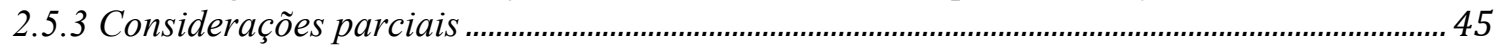

CAPÍTULO 3: ANÁLISE DAS ORAÇÕES GERUNDIVAS COM SUJEITO ORACIONAL . 46

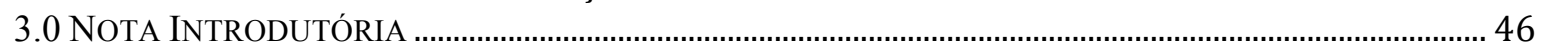

3.1 ANÁLISE PARA AS ORAÇÕES GERUNDIVAS COM SUJEITO ORACIONAL .......................................... 46

3.2 ANÁLISE DOS DADOS - CLASSIFICAÇÃO DAS ORAÇÕES GERUNDIVAS COM SUJEITO

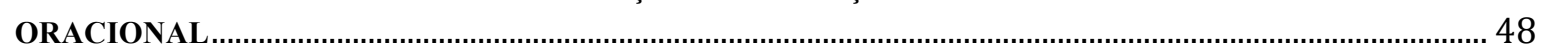

3.2.1 Utilizando testes e análises de Lobo............................................................................................. 49

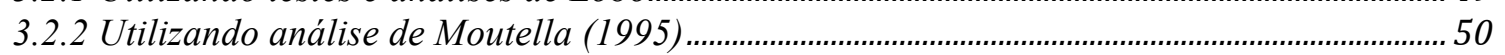

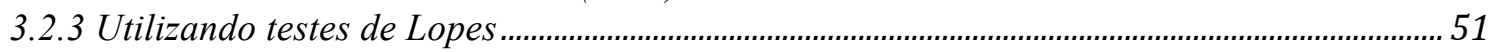

3.3 Conclusão dos testes: análise dos resultados............................................................................. 52 


\section{Introdução}

Este trabalho investiga as propriedades sintáticas de orações gerundivas, nas quais a referência do sujeito é ligada ao conceito expresso por toda a oração principal, como ocorre em (1):

(1) a. Segundo a lei, nos últimos dois anos o índice foi reduzido para zero, tornando a lei mais eficaz, desta forma a proporção de acidentes está cada vez menor.

b. O estado interviu na forma de conscientizar as pessoas por meio de uma lei rigorosa, assim caminhando para um país desenvolvido com segurança e acima de tudo respeito.

c. A participação de todos é indispensável nessa luta contra as infrações, reduzindo assim, as lamentações dos familiares de vítimas de álcool.

d. A conscientização da população só veio com a diminuição do número de mortes em acidentes de trânsito, mostrando os efeitos positivos dessa lei.

e. Começou a gargalhar chamando a atenção dos outros feirantes

Os dados utilizados para a análise foram retirados de redações de alunos que participaram do Exame Nacional do Ensino Médio (ENEM), foram pedidos dados com o seguinte perfil: (i) faixa etária de 17 e 18 anos (alunos e alunas) que fizeram o ENEM no seu último ano do ensino médio como tentativa de ingresso em instituições de ensino de Brasília; (ii) moradores de Brasília - DF; (iii) escolas públicas e particulares; (iv) que fizeram o ENEM de 2013. Recebemos 100 redações e encontramos 87 dados como os mostrados em (1). Tais estruturas foram encontradas também em redações de alunos de escola particular do $9^{\circ}$ ano do ensino fundamental, foi a partir desses dados encontrado em projeto anterior a esta dissertação que percebeu-se a necessidade de analisar tais exemplos, pois eles são recorrentes nas produções textuais de alunos, por isso incluímos um exemplos do $9^{\circ}$ ano, retirado desse projeto preliminar, o exemplo (1e).

Como dito anteriormente, as construções gerundivas a serem estudadas na presente pesquisa têm como sujeito toda a informação contida na oração principal. Sendo assim, na oração em (1a) a referência do verbo da oração gerundiva não é o sujeito da oração principal nem o objeto dela, mas sim toda a informação contida na oração principal de que "o índice foi reduzido para zero". Em outras palavras, pode-se afirmar que foi "a redução do índice para zero" que tornou a lei mais eficaz. No exemplo em (1b), também a referência do verbo da oração gerundiva é toda a informação contida na oração principal, que é a de que "o estado interviu na forma de conscientizar as pessoas por meio de uma lei rigorosa", ou seja, a intervenção do estado fez o Brasil caminhar para um país desenvolvido. Em (1c) a 
informação de que "a participação de todos é indispensável nessa luta contra as infrações" é a referência do verbo da oração gerundiva. Em (1d) o mesmo ocorre, a referência do verbo da oração gerundiva não é algum elemento nominal da oração principal mas toda a informação contida nela, ou seja, “A conscientização da população só veio com a diminuição do número e mortes em acidentes de trânsito". Por fim, em (1e) vemos que foi o começar a gargalhar que chamou a atenção dos outros feirantes, o sujeito da oração gerundiva é, portanto, toda a informação contida na oração principal.

O objetivo da pesquisa é duplo: o primeiro é o de sistematizar as análises feitas no português sobre esse tipo de oração gerundiva e verificar se tais estudos conseguem explicar as propriedades de tais orações ou não, para tanto será apresentado um panorama sobre orações gerundivas em português; o segundo objetivo é o de propor uma análise para tais orações, levando em consideração os estudos previamente investigados.

Um primeiro fato interessante sobre as orações reduzidas de gerúndio com sujeito oracional é a ausência de descrição dessa estrutura em gramáticas tradicionais. Em Cunha \& Cintra (2008), por exemplo, a definição de orações reduzidas consiste na afirmação de que tais orações subordinadas não são iniciadas por pronome relativo nem por conjunção subordinativa e têm o verbo em uma das formas nominais (infinitivo, gerúndio ou particípio).

Para os autores, as orações reduzidas de gerúndio podem ser adjetivas ou adverbiais. Encontramos, em Cunha \& Cintra (2008), o seguinte exemplo para oração subordinada adjetiva reduzida de gerúndio:

(2) a. Virou-se e viu a mulher / dando com a mão / fazendo sinal / para que ele voltasse b. Viu um grupo de homens / conversando.

Em (2a), o verbo da oração gerundiva tem como sujeito a referência ao objeto da oração principal (a mulher) e em (2b) o verbo da oração gerundiva também tem como referente o objeto da oração principal (um grupo de homens).

Em relação à orações subordinadas adverbiais reduzidas de gerúndio, os autores afirmam que estas têm significado principalmente temporal, mas há a possibilidade de orações reduzidas de gerúndio temporais (3a), causais $(3 b)$, concessivas $(3 c)$ e condicionais (3d):

(3) a. Passando hoje pela porta do meu compadre José Amaro, / ele me convidou para tomar conta de sua causa.

b. Pressentindo / que as suas intenções haviam sido adivinhadas, Macedo tentou 
minorar a situação.

c. Aqui mesmo, / ainda não sendo padre, / se quiser florear com outros rapazes, e não souber, há de queixar-se de você, Mana Glória.

d. Pensando bem, / tudo aquilo era muito estranho.

Em (3a) o verbo da oração gerundiva refere-se ao complemento eu, ou seja: eu passei, ele me convidou; em (3b) a oração gerundiva refere-se ao sujeito da oração principal (Macedo), ou seja Macedo pressentiu, o mesmo ocorre em (3c), o referente do verbo da oração gerundiva é o sujeito da oração principal (sujeito desinencial). E, em (3d), a oração gerundiva não parece ter referência clara, é de fato uma condição.

A descrição feita por Castilho (2010, p.382 ex. 122 e 123) apresenta, como contextos de ocorrência das orações gerundivas, as orações com função adjetiva e adverbial. Como exemplo do primeiro caso, temos (4a) que, segundo o autor, tem como correspondente (4b). Como exemplo do segundo caso (gerundiais adverbiais), o autor apresenta (4c) e afirma que tal exemplo pode ser parafraseado como (4d)

(4) a. Ouvimos os vizinhos reclamando do barulho.

b. Ouvimos os vizinhos que reclamavam do barulho.

c. Reclamando do barulho, acabou arranjando encrenca com o vizinho.

d. Porque reclamou do barulho, acabou arranjando encrenca com o vizinho.

Castilho (2010, p.382, ex. 124) ainda apresenta as orações gerundiais ambíguas do tipo Encontrou a garota lavando a roupa (há dúvida em saber quem estava lavando roupa, o sujeito ou a garota) para mostrar a flexibilidade das classificações gramaticais. É importante ressaltar que o autor afirma que o sujeito da sentença gerundial é predominantemente o sujeito da oração principal e que há uma pequena porcentagem de orações gerundivas com sujeito próprio. O autor não aborda, portanto, as orações gerundivas com sujeito oracional ${ }^{1}$.

Em resumo, como se pôde atestar da revisão feita uma gramática tradicional e em uma gramática linguística, a classificação existente não é suficiente para analisar todas as estruturas possíveis de orações reduzidas de gerúndio. Primeiro porque o trabalho de Móia \& Viotti (2004) apresenta diversas interpretações semânticas para as orações adverbiais

\footnotetext{
${ }^{1}$ O estudo de Simões (2007), citado por Castilho (2010), apresenta uma análise detalhada sobre as orações gerundivas dentro de uma perspectiva teórica diferente da adotada nesta dissertação. Os contextos encontrados por esse autor também não incluem as orações gerundivas com sujeito oracional aqui estudadas. $\mathrm{O}$ autor apresenta, quando analisa o sujeito das orações gerundivas, o sujeito oracional (p.256, ex. 113): Nestes pousos falhamos, sendo a causa o requerer toda a Tropa a Anhanguera, e fizesse a resenha que lhe tinha prometido antes de fazer em Mogi, e a que tinha já faltado. Porém é um contexto diferente do que chamamos aqui de orações gerundivas com sujeito oracional. O trabalho de Braga (2007) também analisa as construções de gerúndio, porém, mais uma vez não foi encontrado um exemplo para as orações gerundivas com sujeito oracional no contexto estudado aqui.
} 
reduzidas de gerúndio, e tais interpretações semânticas são bem mais diversas do que somente a classificação tradicional de orações gerundivas adverbiais temporais, causais e condicionais (cf. capítulo 2). Segundo porque há orações substantivas reduzidas de gerúndio do tipo oração subordinada substantiva, em posição de complemento do verbo da oração principal, como defendido por Moutella (1995) e Rodrigues (2007, 2010), e não apenas orações reduzidas de gerúndio do tipo adjetivo e adverbial.

Já os trabalhos linguísticos, de cunho gerativista, sobre orações gerundivas em português, adotam diferentes perspectivas de análise para os diferentes contextos em que tais orações ocorrem. Moutella (1995) define o Sintagma de Aspecto como categoria de projeção máxima do gerúndio e realiza uma análise das orações gerundivas adverbiais, adjetivas e substantivas. Em relação às orações gerundivas com sujeito oracional, a autora cita o exemplos $O$ avião caiu, matando 150 pessoas, e o classifica como oração coordenada; Lopes (2004) analisa as orações gerundivas com sujeito oracional, tais como $O$ avião caiu, deixando vário feridos, como orações relativas apositivas de foco. Lobo (2001, 2003 e 2009) analisa as orações gerundivas no Português Europeu, tal análise inicialmente não parece incluir as orações gerundivas como sujeito oracional, foco do presente trabalho. O interesse no trabalho da autora se dá pelo fato de serem reveladas diferenças sintáticas e semânticas entre as orações reduzidas de gerúndio no português europeu e no português brasileiro. Por fim, Móia \& Viotti (2004) apresentam os valores semânticos associados às orações gerundivas. Apresentam um exemplo que aproxima-se inicialmente aos dados de orações gerundivas com sujeito oracional e será necessária a realização de testes para identificar se tal exemplo apresentado pelos autores é de fato uma oração gerundiva com sujeito oracional.

Por meio da revisão desse tema na literatura, pode-se observar que as orações gerundivas com sujeito oracional são analisadas e classificadas de pelo menos três formas diferentes: (i) orações coordenadas, segundo Moutella (1995); (ii) orações apositivas de foco, segundo Lopes (2004) e (iii) orações adverbiais resultativas, segundo Móia \& Viotti.

Em suma, como apresentado brevemente acima, parece haver duas motivações principais para o estudo das construções gerundivas com sujeito oracional no PB; a primeira surge ao identificar estruturas inovadoras que não são discutidas na gramática tradicional e a segunda consiste na falta de consenso na classificação dessas estruturas nos estudos linguísticos elaborados sob a perspectiva gerativista.

Vimos que é necessária uma nova proposta de análise, nesse sentido propomos uma hipótese, ainda em andamento, de que as orações gerundivas com sujeito oracional comportam-se de forma análoga às orações relativas livres. 
Por fim, considerando os pressupostos teóricos da teoria gerativista, é importante investigar de que forma as propriedades das orações reduzidas de gerúndio com sujeito oracional podem contribuir para que se compreenda a Faculdade da Linguagem e as propriedades das línguas humanas.

O trabalho será dividido em três capítulos. O primeiro apresentará os pressupostos teóricos da presente pesquisa. No segundo capítulo será apresentado um panorama sobre as orações gerundivas em português. No terceiro capítulo serão investigadas, de forma mais detalhada, as propriedades das orações gerundivas com sujeito oracional. Por fim serão apresentadas as considerações finais desta dissertação. 


\section{Capítulo 1: Pressupostos teóricos}

Esta dissertação insere-se na Teoria Gerativa, dessa forma, tem como pressuposto teórico a Faculdade da Linguagem. Nessa perspectiva os seres humanos possuem uma capacidade inata de adquirir língua, a Gramática Universal (GU). Chomsky (1996) afirma o seguinte:

(...) há uma parte da mente/cérebro que é dedicada ao conhecimento e ao uso da linguagem. Trata-se de uma função particular no corpo; é algo como um órgão da linguagem, proximamente análogo ao sistema visual, que também é dedicado a uma tarefa particular. (CHOMSKY,1996, p.18)

Existem evidências que corroboram tal pressuposto, uma dessas evidências consiste na constatação da Pobreza de Estímulos. O conhecimento de língua de um falante é inconsciente, uma pessoa adquire uma determinada língua dependendo de seu contexto social em que aprenderá uma língua possível (inglês, português, etc.) quando ainda bebê. Os estímulos recebidos são parcos e desorganizados, ainda assim, em condições normais, toda criança adquire uma língua.

Para explicar o fato de que, apesar de termos uma diversidade de línguas possíveis no planeta, as crianças têm um processo de aquisição fácil e inconsciente, os gerativistas postulam uma base comum para todas as línguas, ou seja, explicada pela a teoria de Princípios e Parâmetros. A base comum a todas as línguas são os Princípios e os Parâmetros são propriedades que uma língua pode ou não apresentar, e consistem nas diferenças entre as línguas. Chomsky afirma o seguinte sobre esse funcionamento da aquisição de língua:

Os princípios têm validade geral para línguas e construções - de modo que não há nenhum princípio especial para orações relativas ou quaisquer outras construções. As variações paramétricas parecem constituir um espaço finito, significando que, se isso for verdadeiro, há um número finito de possíveis línguas que as contemplem. Ademais, elas parecem ser limitadas a certas 
pequenas partes da língua: a algumas partes do léxico e a certos aspectos periféricos da interface sensório-motora. (CHOMSKY, 1996, p.31)

Resumindo, a GU pode ser vista como uma função que toma os dados linguísticos primários como input e entrega, como resultado, uma gramática particular (a do inglês, português, alemão...).

Dentro da Teoria Gerativa temos o Programa Minimalista, o qual busca construir um sistema sem redundâncias e econômico, com um funcionamento motivado empiricamente e sem conceitos que existam apenas para explicar dados que oferecem problemas para a teoria.

Parte-se do pressuposto de que a linguagem humana possui uma engenharia refinada e simples e não complexa e caótica, afinal toda criança adquire uma língua inconscientemente. Chomsky afirma também que as possíveis imperfeições da teoria, ao necessitar de conceitos não empíricos em determinados momentos, são interessantes, pois evidenciam um ponto a ser analisado mais detalhadamente exatamente por ser um ponto que causa necessidade de explicações menos naturais:

O Programa Minimalista se baseia no pressuposto de que essa é uma questão igualmente séria. Temos, então, a seguinte ordem de intuições a explorar. Primeiro, tentamos submeter pressupostos sobre a linguagem a um escrutínio muito rigoroso para ver se eles são empiricamente válidos, ou apenas uma espécie de conveniência técnica para encobrir lacunas de compreensão. Segundo, quando há qualquer desvio da perfeição, da naturalidade conceitual em satisfazer condições de legibilidade, colocamos um ponto de interrogação e perguntamos se o desvio é justificável. (CHOMSKY, 1996, p.39)

A pergunta, que resume de certa forma o Programa Minimalista, consiste em saber como implementar noções como elegância, beleza, parcimônia, naturalidade etc. no contexto linguístico atual, em que seguimos o Programa Minimalista. É importante elencar os fatos sobre as línguas que qualquer teoria deve considerar. Hornstein, Nunes e Grohmann (2005, p.7) apresentam alguns "fatos importantes", que seriam condições de fronteira para a adequação teórica:

$\mathrm{F}_{1}$ : Sentenças são unidades linguísticas básicas.

$\mathrm{F}_{2}$ : Sentenças são o emparelhamento de forma (som/signos) e significado. 
$\mathrm{F}_{3}$ : Sentenças são compostas de expressões menores (palavras e morfemas).

$\mathrm{F}_{4}$ : Essas unidades menores compõem unidades com estrutura hierárquica (ex.: sintagmas, maiores que palavras e menores que sentenças).

$\mathrm{F}_{5}$ : Sentenças apresentam propriedades de deslocamento (expressões que ocorrem em uma posição podem ser interpretadas em outra).

$\mathrm{F}_{6}$ : A língua é recursiva, ou seja, não há limite para o tamanho de sentenças em qualquer língua natural.

Qualquer teoria incluída no Programa Minimalista deve respeitas esses fatos importantes sobre as línguas. Além disso, deve-se entender o modelo de arquitetura minimalista, o qual pode ser representado da seguinte forma:

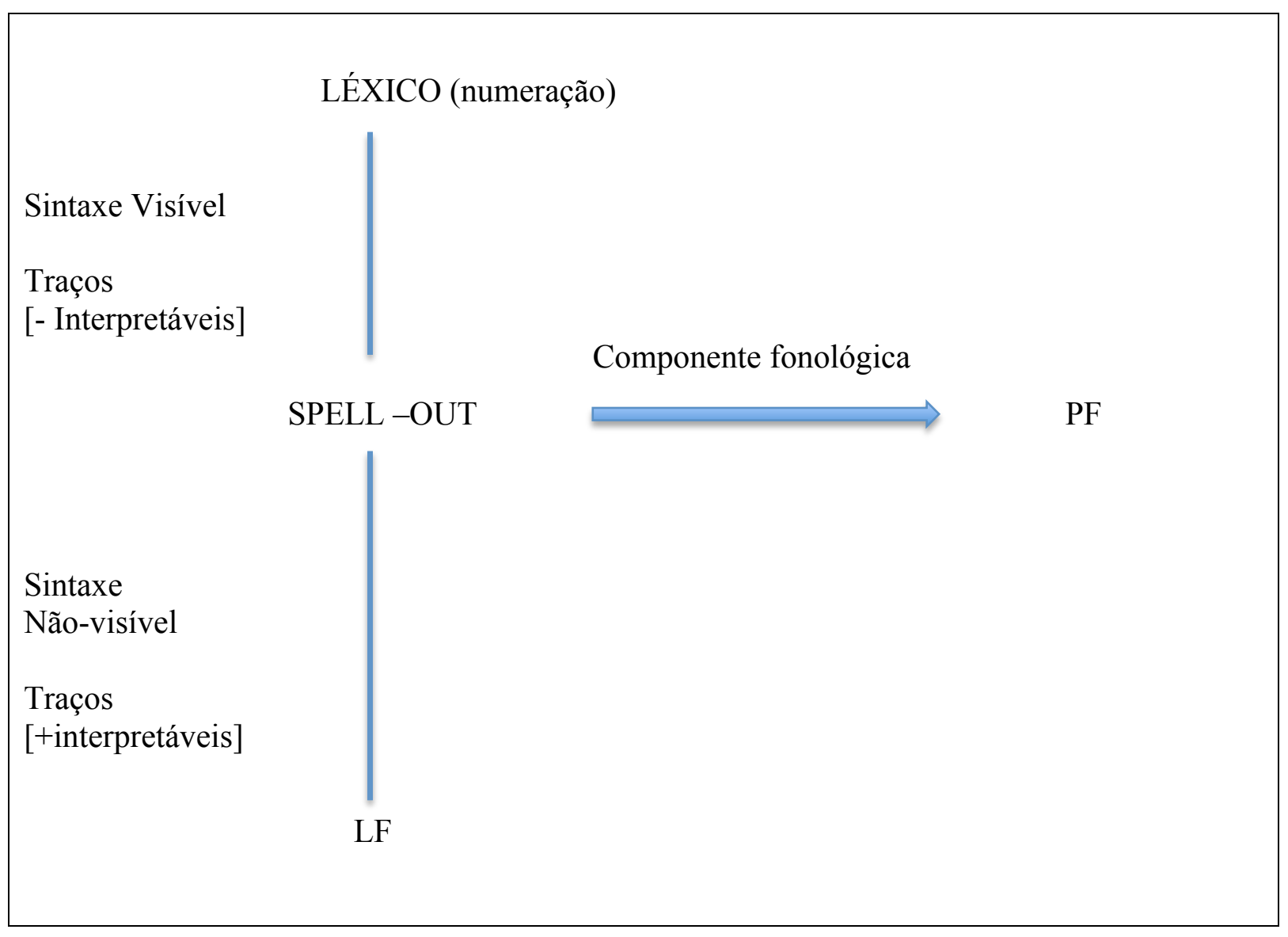

A assunção é a de que a faculdade da linguagem compreende um léxico e um sistema computacional. O léxico especifica os itens que entrarão no sistema computacional e suas propriedades idiossincráticas. O sistema computacional organiza esses itens de forma a obter o par $(\beta, \lambda)$, em que $\beta$ é um objeto de PF e $\lambda$ é um objeto de LF. Esse par está sujeito ao 
princípio de Interpretação Plena ${ }^{2}$, que, se for satisfeito, leva a derivação a convergir em PF e LF; caso contrário, a derivação poderá não convergir (crash).

É importante entender que existem traços interpretáveis e não-interpretáveis. Olhando a representação do modelo de arquitetura minimalista acima, veremos que os traços interpretáveis são aqueles relevantes para LF para atender ao Princípio de Interpretação Plena, por isso serão checados na sintaxe não-visível. Já os traços não-interpretáveis devem ser eliminados antes de LF, pois não são relevantes para essa interface, por isso são checados na sintaxe visível.

Exatamente para encontrar explicações simples e intuitivas, temos dentro da teoria a operação merge, a qual consiste em juntar itens lexicais, organizando-os em estruturas sintagmáticas. Tal operação surge para eliminar pressupostos que eram convenientes apenas dentro da teoria e que não surgiram empiricamente.

$v i u+$ MERGE Maria $\Longrightarrow$ [vp viu Maria]

O modelo também tem como base a ideia de economia, ou seja, determinados movimentos só são feitos se realmente necessários e um elemento só realizará um movimento se não houver nenhum outro elemento que o possa realizar para satisfazer determinada exigência. Para que uma proposta seja adequada para a Teoria Gerativa, dentro do Programa Minimalista, aqueles "fatos importantes" devem ser respeitados, assim como as condições de economia.

Com relação ao comportamento do gerúndio em orações gerundivas, seguiremos o dito por Lobo (2008, p.2). O gerúndio do português é, segundo a autora, uma forma verbal formada pelo tema verbal e pelo sufixo -ndo, tradicionalmente integrada no grupo das formas verbais não finitas, assim como o infinitivo e o particípio:

\section{canta+ndo bebe+ndo dormi+ndo}

Em português padrão, o gerúndio é invariável, não havendo marcas de pessoa depois da desinência. A autora afirma ainda que, ao contrário das orações infinitivas, as orações

\footnotetext{
${ }^{2}$ Todos os traços devem ser legíveis na interface relevante.
} 
gerundivas e participiais não ocorrem em posições argumentais, exceto em casos de gerundivas predicativas (cf. 2.2.1), que são estruturas defectivas. O gerúndio do português tem assim uma distribuição distinta das formas em -ing do inglês (classificadas como gerund ou como present participle).

Lobo (2008, p.2) apresenta algumas diferenças entre as orações gerundivas em português e em inglês, tais diferenças são resumidas na tabela a seguir:

\begin{tabular}{|c|c|c|}
\hline & Inglês & Português \\
\hline \multirow{2}{*}{$\begin{array}{l}\text { Ocorrência em posição de } \\
\text { complemento de verbo ou } \\
\text { de preposição }\end{array}$} & John enjoyed writing the book & $\begin{array}{l}\text { *O João apreciou escrevendo o } \\
\text { livro }\end{array}$ \\
\hline & $\begin{array}{l}\text { After washing his car, John } \\
\text { read his newspaper }\end{array}$ & $\begin{array}{l}\text { *Após lavando o carro, o João } \\
\text { leu o jornal }\end{array}$ \\
\hline $\begin{array}{l}\text { Gerúndio dando origem à } \\
\text { nominalização }\end{array}$ & The breaking of bread & *O partindo do pão \\
\hline
\end{tabular}

A autora mostra ainda que somente as orações finitas e infinitivas podem ocorrer como complemento de verbo ou de preposição, ou seja, em contextos nominais.

Outra característica das orações gerundivas, em português, refere-se à sua impossibilidade de ocorrerem introduzidas por conectores, que tipicamente introduzem domínios finitos (quando, se...), como acontece nas orações adverbiais finitas. As orações gerundivas também não são nominais, por isso não podem ser introduzidas por conectores de tipo preposicional (por, para...), como acontece nas adverbiais infinitivas. Embora as gerundivas não tenham conectores preposicionais, podem ter conectores de tipo adverbial, como mesmo ou embora: Mesmo chegando atrasado, podes entrar.

Lobo (2008) propõe que o domínio funcional das orações gerundivas, ao contrário do das orações finitas e infinitivas, não contém traços nominais. Isso impede a oração gerundiva de ocorrer em posições argumentais. As gerundivas predicativas (cf. 2.2.1) serão estruturas funcionalmente defectivas, em que Tempo do gerúndio não é diretamente ligado por um núcleo temporal. Assim, as gerundivas adjuntas serão categorialmente CPs cujo núcleo contém traços-T não interpretáveis. 


\section{Capítulo 2: Quadro teórico sobre gerundivas: contextualização}

\section{Nota introdutória}

Neste capítulo exponho com certo detalhe seis estudos sobre o gerúndio oracional no português. O objetivo mais uma vez é duplo, primeiramente pretendo apresentar uma visão abrangente de como o fenômeno das orações gerundivas tem sido analisado na literatura gerativista. Tendo em vista o objetivo de construir um panorama sobre o assunto, incluirei alguns estudos que analisam orações gerundivas, mas que não tratam somente das orações gerundivas com sujeito oracional. Em segundo lugar, pretendo verificar quais das análises apresentadas são capazes de dar conta das propriedades das orações gerundivas com sujeito oracional. Para tanto, serão analisados os trabalhos de Moutella (1995), Lobo (2001, 2003, 2008), Rodrigues (2007, 2010) e Lopes (2004).

\subsection{Moutella (1995): caracterização sintática de orações gerundivas em português brasileiro.}

O objetivo geral de Moutella (1995) é estabelecer um quadro distribucional dos contextos em que ocorrem orações reduzidas de gerúndio no PB, para tanto analisa todos os tipos de orações reduzidas de gerúndio em português brasileiro.

Para a autora, o gerúndio oracional corresponde à projeção máxima SAsp, em que o morfema de gerúndio projeta um Sintagma de Aspecto (Moutella, 1995 p.51):

(...) a noção aspectual é inerente ao gerúndio, e, do mesmo modo que se reconhece que as formas verbais flexionadas, que apresentam morfema de tempo, modo e pessoa gramatical, projetam Sintagma de Tempo e Sintagma de Concordância, também se reconheceria que o morfema -ndo, que expressa uma noção aspectual, projeta um Sintagma de Aspecto. 
(5)

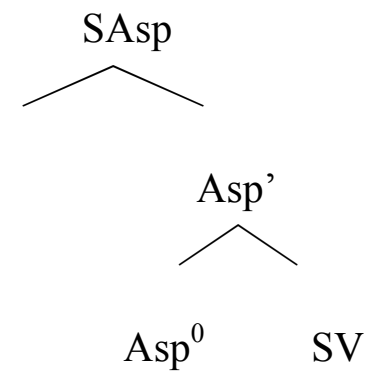

Para a autora, o gerúndio possui uma noção aspectual inerente e independente do Tempo da Matriz. Tal noção aspectual corresponde ao traço de [- Concluso]. O Sintagma de Aspecto deve estar em uma relação de c-comando com o Sintagma de Tempo, ou seja, sob escopo do Tempo da matriz, para que o enunciado seja gramatical. O gerúndio, portanto, não ocorre em construções com um verbo auxiliar com noção aspectual de [+Concluso] dada lexicalmente, como é o caso do auxiliar ter em (2) (p.56):

(6) a. *Ela tinha lendo esse livro

Moutella apresenta noções gerais sobre a distribuição das orações de gerúndio para mostrar que o gerúndio possui comportamento nominal (exatamente por não aceitar qualquer tipo de flexão de pessoa ou tempo ${ }^{3}$ ), mas também possui comportamento verbal, como em (7) (p.63, exemplo 57):

(7) a. Não valorizou a sua hipótese, eliminando-a da argumentação

b. Pedro/Ele chegando, começaremos a reunião

c. Amanhã, eles estarão negociando com o governo

d. Sendo aceita a proposta, iniciaremos as atividades imediatamente

Os exemplos de (7a-d) demonstram o comportamento verbal do gerúndio, pois em (7a) demonstra-se que orações gerundivas licenciam complementos idênticos aos das formas verbais finitas cognatas, atribuindo-lhes Caso acusativo; em (7b) demonstra-se a possibilidade de haver sujeito manifesto representado por sintagma nominal pleno ou

\footnotetext{
${ }^{3}$ Em algumas variedades do português europeu é possível encontrar flexão de pessoa e número no gerúndio, veja o exemplo em Lobo (2001, p. 369):

(720) Tu querendos, podemos namorar às escondidas. (Monte Gordo, in Ratinho 1959)

(721) Qualquer descuido, os animais soltandem-se... (Santa Justa, ALEPG)
} 
pronome nominativo; em (7c) o gerúndio entra na constituição de locuções verbais e em (7d) o gerúndio expressa aspecto verbal e permite voz passiva.

É importante ressaltar que, pelo fato do verbo no gerúndio possuir propriedades verbais, este sempre terá um sujeito, segundo a autora. Nos exemplos da autora o sujeito é um termo da oração principal e nos casos estudados nesta dissertação o sujeito da oração reduzida é toda a informação contida na oração principal.

Após apresentar as propriedades gramaticais do gerúndio a autora apresenta sua classificação para as orações gerundivas: orações adjetivas reduzidas, orações substantivas reduzidas e orações adverbiais reduzidas. As características dessas orações serão apresentadas as seguir.

\subsubsection{Orações adjetivas reduzidas}

Ao iniciar seu quadro distribucional a autora analisa as orações adjetivas reduzidas. Moutella (1995) defende que o gerúndio, como modificador do nome, vem adjunto ao sintagma nominal que modifica, e equivale, portanto, a uma oração subordinada adjetiva restritiva. O sujeito da oração reduzida seria um pro coindexado com a expressão nominal antecedente, tal como em (8) (p.73, exemplo 72):

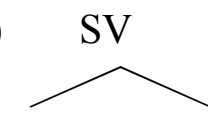

pro
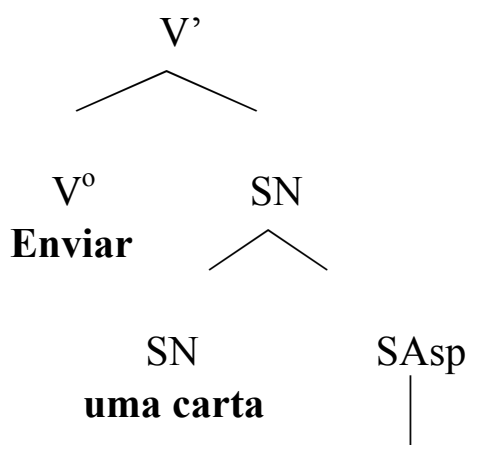

contendo acusações

Há, no entanto, situações em há dois elementos nominais possíveis para a coindexação, ambos satisfazem as exigências semânticas de argumento externo do verbo no 
gerúndio. Nesses casos ela será feita por $\mathrm{PRO}^{4}$, e caso não haja uma restrição semântica para a coindexação, seria escolhido o elemento na posição de sujeito, o que evidencia a restrição distribucional da oração de gerúndio como modificadora de sintagma nominal como em (10) (p.74, ex. 75):

(10) a. O repórter mencionou um decreto ${ }_{i}\left[\mathrm{PRO}_{\mathrm{i}}\right.$ regulando as operações financeiras]

b. $\mathrm{O}$ autor $_{i}$ refuta a análise de Giusti $\left[\mathrm{PRO}_{i}\right.$ propondo uma série de 5 vogais]

Em (10a) o sujeito da gerundiva pode estar coindexado a $O$ repórter ou a um decreto, nesse caso as restrições semânticas fazem com a coindexação de PRO seja feita com um decreto. Já em (10b) não há restrição semântica, nesse caso a coindexação deve ser feita com o sujeito da oração principal. Ou seja, quando a oração for ambígua como em (10b) a coindexação de PRO é feita com com o sujeito da oração principal segundo a autora.

Moutella afirma que essa análise da distribuição da gerundiva mostra que a coindexação do sujeito do gerúndio não se dá exclusivamente com o sujeito da matriz e é a noção de convergência dos traços semânticos e sintáticos das categorias das sentenças que pode explicar as diferentes estruturas em (10).

Outra característica distribucional do gerúndio, como oração adjetiva restritiva, consiste no desígnio de atributos permanentes, devido a seu traço aspectual de [- Concluso]. Portanto, as orações gerudivas deveriam ser compatíveis apenas com verbos de traço [+Dinâmico], porém, como a autora mostra, em (11) abaixo, a oração gerundiva é compatível com verbos estativos de traço [-Dinâmico] (p.75, ex 77):

(11) a. A compra de um livro [contendo ilustrações] deixou-o feliz

b. *A compra de um livro que está contendo ilustrações deixou-o feliz.

Os exemplos acima também demonstram, segundo a autora, que as orações gerundivas não são derivadas das orações relativas desenvolvidas por simples apagamento do conectivo, pois a tentativa de uma contraparte desenvolvida de (11b) não é possível, como se pode ver em (11c).

\footnotetext{
${ }^{4}$ Em Neto \& Silva (2012) explica-se que PRO é uma categoria vazia [+pronominal] e [+anafórica], tal categoria não possui uma contraparte manifesta. É diferente, por exemplo, de pro, que também é uma categoria vazia, que é [+pronominal] e [-anafórica] e sua "contraparte" visível, ou seja a categoria visível equivalente é a categoria dos pronomes.
} 


\subsubsection{Orações subordinadas substantivas reduzidas: um caso não descrito pelas gramáticas tradicionais}

Moutella (1995) também demonstra que a gramática tradicional não descreve a possibilidade de existirem orações subordinadas substantivas reduzidas de gerúndio. Tradicionalmente, só haveria a possibilidade de orações subordinadas adjetivas reduzidas e adverbiais reduzidas. No entanto, a autora mostra que existe a possibilidade de orações reduzidas de gerúndio ocuparem a posição de objeto de verbos sensitivos. Para entender o que a autora deseja apresentar, analisemos o exemplo em (12) (p.79, ex.81):

(12) a. Maria viu [os meninos brincando].
b. Maria viu os meninos [brincando].

Nesse caso, a oração gerundiva [os meninos brincando] pode desempenhar a função de complemento verbal (objeto direto) do verbo ver. Na verdade, segundo a autora, parece haver a possibilidade de uma dupla interpretação: (i) uma em que o gerúndio constitui uma oração relativa reduzida (12b), e (ii) uma em que há uma oração gerundiva em posição de objeto (12a).

Em resumo, a dupla interpretação consiste nas possibilidades de adjunção a SN (ou seja, o gerúndio constitui uma oração adjetiva reduzida de gerúndio) ou de estrutura de complementação a $\mathrm{V}^{0}$ (ou seja, a oração de gerúndio é objeto do verbo da oração matriz).

Em seguida, Moutella apresenta os seguintes exemplos, que também serão importantes para o entendimento da análise desse tipo de oração, em que a oração gerundiva é complemento do verbo da matriz (p.89, ex.102 e 103):

- Orações de gerúndio como argumento interno do verbo

(13) a. Não aguento mais [esses garotos chegando tarde todo dia]

b. Já permitem [menores dirigindo sem carteira?]

c. Prefiro [a Paula tocando violão] a ouvir música sertaneja

d. Prepare-se para assistir [Ana, mais uma vez, brigando com Pedro]

e. Achava uma absurdo [os doentes esperando horas] para serem atendidos

f. Eu acredito [no ministro consertando as finanças]

g. Não quero [alunos fumando na sala de aula]

h. Você perdeu [a Juliana quase se ajoelhando] para ele voltar com ela

i. Quero [todos os alunos entregando o trabalho até quarta-feira] 
- Orações de gerúndio como argumento externo do verbo

(14) a. É lamentável [você virando a casaca]

b. É uma piada [alguns políticos querendo interferir no Judiciário]

c. Não é aconselhável [os meninos saindo a essa hora sozinhos]

d. Foi fera [a banda tocando aquelas duas músicas no final]

e. Não me agrada [os meninos saindo de carro sem carteira]

f. Deve incomodar muito você [os vizinhos tocando guitarra à noite]

g. É antitelevisivo [uma pessoa falando diante das câmeras sem movimento]

A autora, portanto, afirma o seguinte sobre esses exemplos:

Depreende-se do exame dos dados em (102) e (1103) que a oração de gerúndio na posição de argumento do verbo tem sempre a posição de sujeito ocupada por um sintagma nominal cujo papel temático é o de agente. A generalização a que chegamos é a de que essas orações de gerúndio representam sempre uma "cena", uma situação que se caracteriza pelo traço [+Dinâmico]. (MOUTELLA 1995, p. 90))

\subsubsection{Orações subordinadas adverbiais reduzidas}

Ao abordar as orações gerundivas adverbiais, Moutella afirma que o gerúndio substitui conjunções que, nas orações desenvolvidas, possuem papel essencial para a interpretação semântica. Nesses casos, porém, o gerúndio em si não expressa uma função semântica particular e a posição dele em relação à matriz pode mudar a interpretação da sentença como um todo.

A autora afirma que as orações gerundivas adverbiais que indicam maneira ou meio vêm à direita da matriz (nesse caso há um traço aspectual de [- Concluso] e o sujeito é representado por uma categoria vazia coindexada ao sujeito da matriz). Já as orações gerundivas que expressam as demais noções semânticas podem vir à direita ou à esquerda, como se atesta em (15) e (16) (1995, p.95 e 96, ex. 114 e 115):

(15) a. João fala [gaguejando].

(16) a. ??Gaguejando, João fala. 
Em (15) e (16) se demonstra como as orações adverbiais reduzidas de gerúndio que expressam maneira ou meio não podem vir à esquerda da matriz. Os exemplos a seguir também são apresentados pela autora (p.96, ex.116):
a. Ele mastigava a comida [falando sobre política].
(Maneira)
a'. [Falando sobre política], ele mastigava a comida.
(Maneira)
b. Ele mastigava a comida [fazendo barulho].
(Maneira)
b'. [Fazendo barulho], ele mastigava a comida.
(Simultaneidade)

Segundo Moutell (1995), nos exemplos acima, percebemos que os traços semânticos dos verbos definem a função semântica de maneira da oração de gerúndio e a mudança de posicão pode ou não mudar a noção expressa. Em (17b) a noção é de maneira e quando muda-se a posição em (17b') a noção passa a ser de simultaneidade.

A autora afirma que essa distribuição leva à seguinte conclusão (1995, p.97):

O Sintagma de aspecto expressando maneira tem obrigatoriamente o sujeito coindexado com o sujeito da matriz, ao passo que, expressando outras noções circunstanciais, pode haver disjunção do sujeito do gerúndio e do sujeito da oração matriz, o que parece indicar que, nesta última situação, a adjunção se dá no nível mais alto. Propomos que a oração de gerúndo de maneira, em virtude das evidências de restrições em ocupar a posição inicial na sentença, está em adjunção ao sintagma verbal, e a orações de gerúndio que indicam as demais circunstâncias (tempo, condição, causa, concessão) estão adjuntas ao sintagma de tempo.

\subsubsection{Orações gerundivas com sujeito oracional}

Por fim, Moutella (1995) faz um breve comentário para mostrar estruturas em que o sujeito do gerúndio não está coindexado ao sujeito da matriz, mas se refere à situação descrita nessa oração como um todo. A autora apresenta, em seguida, os seguintes exemplos (p.69, ex.63):

(18) a. O avião caiu, matando 150 pessoas.

b. O clima está seco, causando desidratação.

Para esta autora, essas construções aproximam-se das orações coordenadas: Avião cai e mata 150 pessoas. O trabalho de Moutella não traz mais nenhuma contribuição no que se diz respeito a esse tipo de estrutura.

\subsubsection{Considerações parciais}


Como se pôde ver, Moutella (1995) faz uma panorama das possibilidades de classificação das orações gerundivas, demonstra que as restrições distribucionais do gerúndio são principalmente de natureza semântica e estão relacionadas a noções aspectuais. A autora define o Sintagma de Aspecto como categoria de projeção máxima do gerúndio. Em sua análise distribucional, aponta a inovação no português brasileiro em empregar o gerúndio oracional em estruturas de complementação, em posição de argumento do verbo da oração principal.

No que diz respeito às orações gerundivas com sujeito oracional a autora afirma que tais orações são semelhantes a orações coordenadas. Tal equivalência será analisada nesta dissertação com mais detalhe (cf.cap.3).

\subsection{Lobo (2001, 2003 e 2008): classificação das orações gerundivas em português europeu}

Os trabalhos de Lobo (2001, 2003 e 2008) analisados nessa dissertação apresentam uma classificação inovadora para as orações gerundivas no português europeu. Há também testes elaborados pela autora para diferenciar os tipos de orações gerundivas adjuntas. A análise e a classificação feitas por Lobo serão usadas para identificar algumas diferenças entre português brasileiro (PB) e português europeu (PE).

\subsubsection{Lobo 2001: gerundivas predicativas e gerundivas adjuntas}

Lobo (2001a) apresenta o uso predicativo do gerúndio e as gerundivas adjuntas. O uso predicativo do gerúndio consiste em contexto em que a oração gerundiva fica em posição argumental. As orações adjuntas não ocupam posição argumental, são adjungidas, elas podem ser de frase ou de predicado. A primeira diferença entre orações gerundivas em função predicativa e o gerúndio em oração adjunta consiste nas restrições aspectuais ao predicado: nesta última todos os tipos de predicado são possíveis, enquanto nas primeiras há uma restrição e elas não podem ocorrer em predicados estativos. A tabela a seguir, resume essas informações: 


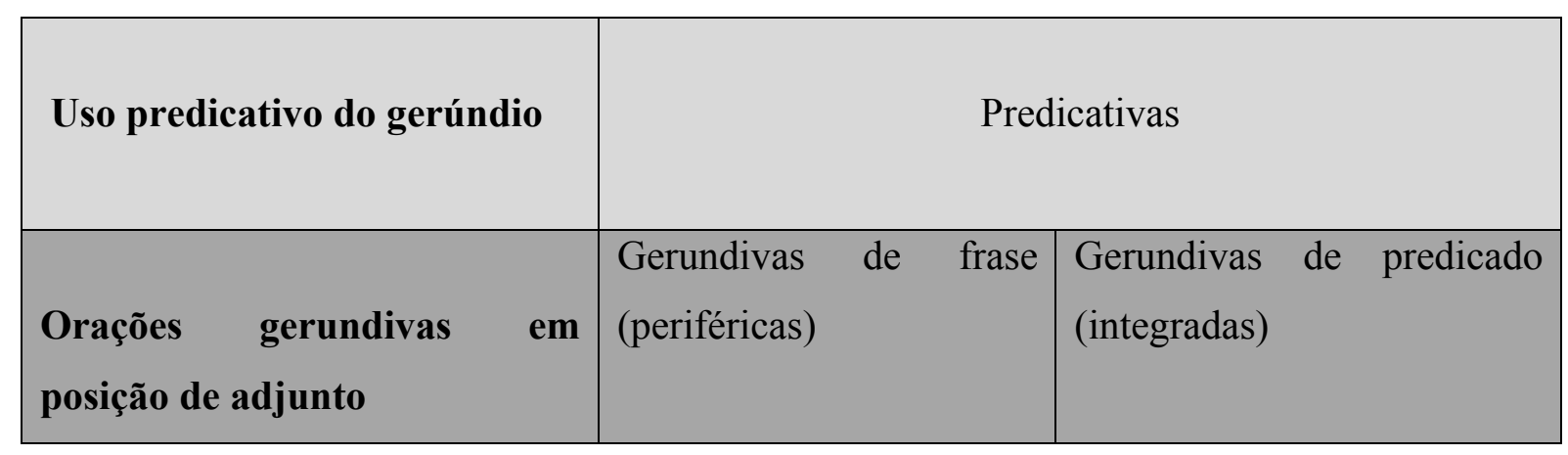

Depois de demonstrar a diferença entre orações adjuntas e o uso predicativo do gerúndio, a autora passa a mostrar, em seguida, dentro das orações gerundivas adjuntas, a diferença entre orações gerundivas de frase (periféricas) e as orações gerundivas de predicado (integradas). Ou seja, as orações adjuntas são divididas em: orações gerundivas de frase e de predicado. Vejamos as possíveis interpretações semânticas de cada uma (p.5 e 6, ex. 33 a 46):

\section{Orações gerundivas de frase}

\section{causa}

(48) Havendo poucas inscrições, o atelier fechou

(49) Chegando atrasado, O Zé já não arranjou lugar sentado

concessão (introduzidas por mesmo, embora...)

(50) Mesmo tendo chegado atrasado, o Zé conseguiu acompanhar a aula

(51) Mesmo havendo poucas inscrições, o atelier não fechará

\section{tempo}

(52) Tendo as crianças adormecido, os pais foram deitar-se

(53) Estando os meninos a dormir, o pai ouviu um estrondo enorme

\section{Orações gerundivas de predicado}

\section{Modo/meio}

(54) Os ladrões arrombaram a porta usando um martelo

(55) As andorinhas construiram os ninhos juntando pequenos ramos

\section{Condição/modo}

(56) Os atletas teriam melhores resultados treinando mais horas por dia

(57) O Zé teria menos dores ficando deitado

\section{Tempo}

(58) O Zé encontrou a solução para o problema passeando pela cidade

(59) O Zé recebou a notícia estando de férias nos EUA 
Com o objetivo de resumir e organizar as classificações e análises feitas pela autora, apresento a seguinte tabela:

\begin{tabular}{|l|l|l|l|}
\hline $\begin{array}{l}\text { Uso predicativo do } \\
\text { gerúndio }\end{array}$ & \multicolumn{1}{|c|}{ Predicativas } \\
\hline \multirow{2}{*}{$\begin{array}{l}\text { Orações gerundivas em } \\
\text { posição de adjunto }\end{array}$} & $\begin{array}{l}\text { Gerundivas de frase } \\
\text { (periféricas) }\end{array}$ & Causa \\
\cline { 3 - 4 } & $\begin{array}{l}\text { Cencessão } \\
\text { (integradas) }\end{array}$ & Tempo \\
\cline { 3 - 4 } & & Condivasão/modo \\
\cline { 3 - 4 } & & Tempo \\
\hline
\end{tabular}

A distinção das orações adjuntas em gerundivas de frase (ou periféricas) e gerundivas de predicado (ou integradas) demonstra que há maior dependência do predicado da matriz no caso destas últimas, o que se traduz, segundo Lobo, em maior restrição interna.

\subsubsection{TESTES com Orações gerundivas em posição de adjunto: gerundivas de frase (ou periféricas)}

Os exemplos de (60) a (66) mostram restrição para as orações gerundivas de frase no que diz respeito à possibilidade de sujeito nulo arbitrário, sujeito nulo co-referente com objeto direto e sujeito nulo co-referente com objeto preposicionado (p.15: 101 a 107):

\section{Sujeito nulo expletivo}

(60) a. [-] Tendo chovido durante toda a tarde, o jardim estava todo molhado.

b. *O Zé queria ter chovido durante toda a tarde.

\section{sujeito nulo arbitrário}

(61) [-] Fumando mais de um maço por dia, aumenta o risco de surgimento de cancro do pulmão.

\section{Sujeito nulo co-referente com sujeito matriz}

(62) [-] Estando doente, o João ficou em casa.

\section{Sujeito nulo identificado por tópico>}

(63) a. [O bebe $]_{i}$ está com febre há três dias. [- $]_{\mathrm{i}}$ Continuando assim, acho que o devemos levar ao médico. 
b. $[\text { Eles }]_{\mathrm{i}}$ construiram já duas casas. [- $]_{\mathrm{i} / ? \text { ? }}$ Acabando de fazer a terceira, [a mãe $]_{\mathrm{j}}$ poderá ir morar para o pé deles.

\section{Sujeito nulo co-referente com DP em encaixada}

(64) a. ??[- $]_{i}$ Estando com febre, a mãe achou que era melhor [o Zé] $]_{i}$ ficar em casa.

b. ??[-] Estando com febre, não me agrada que [o Zé $]_{i}$ vá à escola.

\section{Sujeito nulo co-referente com objeto directo}

(65) $?^{*}[-]_{\mathrm{i}}$ Sendo muito nervosa, o Zé tenta não afligir [a mãe $]_{\mathrm{i}}$.

\section{Sujeito nulo co-referente com objecto preposicionado}

(66) $?^{*}[-]_{\mathrm{i}}$ Estando um pouco deprimida, o Zé resolveu falar com [a amiga $]_{\mathrm{i}}$.

\subsubsection{TESTES com Orações gerundivas em posição de adjunto : gerundivas de predicado (ou integradas)}

Os exemplos de (67) a (75) demonstram maiores restrições em orações gerundivas de predicado com a agramaticalidade com sujeito nulo expletivo em (67) e (68), a agramaticalidade do controle pelo agente com sujeitos animados em (69b), a agramaticalidade de controle pelo agente com sujeitos não animados em (70b) e (71), agramaticalidade no controle pelo objeto em (72) e (73) e ainda a restrição em construções com sujeito sem antecedente em (74) e (75), (p.15: 108 a 116):

\section{Sujeito nulo expletivo}

(67) a. ?*O João não foi para o trabalho [-]chovendo torrencialmente.

b. O João não foi para o trabalho, \# chovendo torrencialmente.

(68) a.?*Os atletas teriam melhores resultados chovendo menos.

b. Os atletas teriam melhores resultados, \# chovendo menos.

c. Os atletas teriam melhores resultados treinando mais.

\section{Controle pelo sujeito matriz/?*pelo agente com sujeitos animados}

(69) a. Os bandidos ${ }_{\mathrm{i}}$ amarraram a velhota [c.v. $]_{\mathrm{i}}$ usando um arame.

b. A velhota $\mathrm{j}_{\mathrm{j}}$ foi amarrada pelos bandidos $\mathrm{i}_{\mathrm{i}}[\mathrm{c} . \mathrm{v} .]_{? * *_{\mathrm{i}} / \mathrm{j}_{\mathrm{j}}}$ usando um arame.

Controle pelo sujeito/?*pelo agente com sujeitos não animados

(70) a. O João pôs o carro a andar empurrando-o.

b. ?*O carro foi posto a andar pelo João ${ }_{i}[-]_{i}$ empurrando-o.

(71) a. O João destruiu a carta queimando-a.

b. ?*A carta foi destruída pelo João queimando-a.

a'. O João destruiu a carta queimando-a ou rasgando-a?

b'. ?*A carta foi destruída pelo João queimando-a ou rasgando-a?

a'.?Foi queimando-a que o João destruiu a carta. 
$b^{\prime}$.*Foi queimando-a que a carta foi destruída pelo João.

\section{* Controle pelo objeto}

(72) A Ana $a_{i}$ abraçou a Teresa ${ }_{j}[\text { c.v. }]_{i} / *_{j}$ chorando muito.

(73) *Esse livro impressionou o João chorando muito.

\section{Sujeito sem antecedente}

(74) ??Este museu foi recuperado aproveitando subsídios europeus.

(75) ??Mataram-se milhares de pessoas invocando o nome de Deus.

Em resumo, na pesquisa de Lobo (2001a), a autora mostrou a diferença entre o uso predicativo do gerúndio e as gerundivas adjuntas, nesse último caso há divisão em gerndivas de frase e gerundivas de predicado. As diferenças entre os tipos de gerundivas adjuntas ficará mais claro no trabalho apresentado a seguir.

\subsubsection{Lobo (2003): Orações gerundivas integradas e periféricas}

Neste trabalho, a autora detalha ainda mais as diferenças entre as orações gerundivas adjuntas periféricas e integradas. Observemos mais uma vez a tabela a seguir para entendermos as diferenças:

\begin{tabular}{|l|ll|l|}
\hline $\begin{array}{l}\text { Uso predicativo do } \\
\text { gerúndio }\end{array}$ & \multicolumn{3}{|c|}{ Predicativas } \\
\hline $\begin{array}{l}\text { Gerundivas em posição de } \\
\text { adjunto }\end{array}$ & $\begin{array}{l}\text { Gerundivas Periféricas (de } \\
\text { frase) }\end{array}$ & $\begin{array}{l}\text { Gerundivas integradas (de } \\
\text { predicado ) }\end{array}$ \\
\hline
\end{tabular}

Conforme apresentado na tabela acima, as gerundivas de frase serão, a partir daqui, chamadas de gerundivas periféricas e as gerundivas de predicado serão chamadas de gerundivas integradas.

As gerundivas periféricas têm menos restrições sintáticas do que as gerundivas integradas, as quais são mais dependentes (temporalmente e semanticamente) do predicado da matriz. O trabalho de Lobo (2003) apresenta um estudo sobre as orações adverbias, aqui será importante apresentar as contribuições relacionadas às orações adverbiais gerundivas. A 
autora apresenta elementos definidores da distribuição sintática das adverbiais e as propriedades que esse tipo de estrutura manifesta.

Quando inicia a abordagem das orações adverbiais gerundivas e participiais, a autora nos oferece a seguinte pergunta (2003, p.13):

Se o estatuto informacional das orações adjuntas finitas e infinitivas é parcialmente determinado por traços discursivos dos seus conectores, como se pode dar conta das orações gerundivas e participiais das línguas românicas, que habitualmente não têm conectores?

Sua análise, portanto, consiste em identificar as diferenças existentes entre orações reduzidas gerundivas e as infinitivas e finitas. Antes mostra, ainda, a diferença entre o gerúndio do inglês (nominal), o gerúndio do português (verbal) e infinitivo do português, a seguir os testes (p. 14 e 15, ex.133 a 140):

\section{Posições argumentais}

(76) a. John prefers washing his car on weekends

b. *O João prefere lavando o carro no fim de semana

b'. O João prefere lavar o carro no fim de semana

(77) a. After washing the car, John read his newspaper

b. *Depois (de) lavando o carro...

b' Depois de lavar o carro...

(78) a. John enjoyed [writing the book]. (Milsark 1988:612)

$\mathrm{b}$ *O João apreciou escrevendo o livro

b' O João apreciou escrever o livro

\section{Nominalizações}

(79) a. the washing of the car

b. *o lavando do carro

A diferença na distribuição sintática comprovada acima demonstra, segundo a autora, que as orações gerundivas em português seriam de natureza verbal e morfologicamente defectivas, enquanto no inglês seriam morfologicamente ambíguas entre categorias nominais e categorias verbais (gerund e present participle).

A distribuição de gerundivas integradas e gerundivas periféricas, consiste, segundo Lobo, nas diferentes possibilidades de interpretação semântica do gerúndio. As construções 
adverbiais periféricas são constituídas das gerundivas causais, concessivas e de tempo anterior, já as gerundivas integradas são constituídas das gerundivas de modo, meio, tempo simultâneo e condicionais.

2.2.3. Lobo (2009): Uso predicativo do gerúndio e orações gerundivas adjuntas: quadros explicativos

Lobo (2009) analisa com mais detalhes o uso predicativo do gerúndio ${ }^{5}$. Vejamos os exemplos em (80) (2008, p. 2: 8):

(80) a. [a Ana dançando o fandango] era um espetáculo digno de se ver

b. O Rui viu [ a Ana dançando o fandango]

Nesses casos temos uma oração reduzida em que o gerúndio funciona como predicado e tem distribuição equivalente à de um PP, um AP ou de um infinitivo preposicionado. Nesse caso estamos analisando as predicativas e não as adjuntas, como podemos ver, novamente, na tabela abaixo:

\begin{tabular}{|l|l|l|}
\hline $\begin{array}{l}\text { Uso predicativo do } \\
\text { gerúndio }\end{array}$ & \multicolumn{1}{|c|}{ Predicativas } \\
\hline \multirow{2}{*}{$\begin{array}{l}\text { Orações gerundivas em } \\
\text { posição de adjunto }\end{array}$} & $\begin{array}{l}\text { Gerundivas de frase } \\
\text { (periféricas) }\end{array}$ & Causa \\
\cline { 3 - 4 } & $\begin{array}{l}\text { Cerundivas de predicado } \\
\text { (integradas) }\end{array}$ & Modo/meio \\
\cline { 3 - 4 } & & Condição/modo \\
\cline { 3 - 4 } & & Tempo \\
\hline
\end{tabular}

\footnotetext{
${ }^{5}$ As orações gerundivas não podem ocorrer em posição argumental. O uso predicativo do gerúndio permite que as gerundivas fiquem nessa posição de argumento porque são estruturas funcionalmente defectivas, em que o Tempo do gerúndio não é diretamente ligado por um núcleo temporal. Tirando esse caso, as orações gerundivas não ocupam posição de complemento de verbo ou de preposição (cf. capítulo 1)
} 
Em seguida Lobo mostra que essas estruturas podem ser substituídas por a + infinitivo ou por predicados preposicionados, adjetivais ou participais (p.3, ex. 8a-b, 9a e 10a):

(81) a. A Ana dançando o fandango era um espetáculo digno de se ver

(82) a. A Ana a dançar o fandango era um espetáculo digno de se ver

(83) b. O Rui viu a Ana dançando o fandango

(84) a. O Rui viu a Ana a dançar o fandango

Segundo a autora, existem as seguintes possibilidades de uso predicativo do gerúndio (p.5, ex. 21b, 22a, 23, 24a e 25a):

(85) b. Figo chutando a bola para Ronaldo (orações aparentemente não dependentes)

(86) a. O João viu o Paulo cantando (predicativo do objeto)

(87) A Ana andando de burro era um espetáculo digno de se ver (posição de sujeito)

(88) a. A cara da Ana olhando para José não engana ninguém (predicando sobre um DP)

(89) a. O João entrou em casa cantando (adjunto predicativo do sujeito)

A autora passa a analisar as orações adjuntas, ou seja, as orações gerundivas integradas e periféricas. Com relação às gerundivas adjuntas, a autora realiza testes para evidenciar as diferenças sintáticas entre as orações gerundivas adjuntas - integradas ou periféricas. Para facilitar a compreensão, os contextos semânticos e os testes foram resumidos nos quadros apresentados a seguir. $\mathrm{O}$ primeiro resume os contextos de interpretação das orações gerundivas e o segundo mostra os testes realizados pela autora.

No quadro abaixo será possível observar: (i) que gerundivas adjuntas permitem diversas interpretações semânticas e (ii) que essas interpretações serão distribuídas em duas classificações. 


\begin{tabular}{|c|c|c|}
\hline & Gerundivas Integradas & Gerundivas Periféricas \\
\hline Causa & & $\begin{array}{l}\text { - Havendo poucas inscrições, o atelier fechou } \\
\text { 'Como havia poucas inscrições...' } \\
\text { - Chegando atrasado, o Zé já não arranjou } \\
\text { lugar sentado } \\
\text { 'Como chegou atrasado..' } \\
\text { - Tendo dormido pouco, o Zé sentia-se cansado } \\
\text { 'Como tinha dormido pouco,...' }\end{array}$ \\
\hline Concessão & & $\begin{array}{l}\text { - Mesmo tendo chegado atrasado, o Zé } \\
\text { conseguiu acompanhar a aula } \\
\text { 'Apesar de ter chegado atrasado...' } \\
\text { - Mesmo havendo poucas inscrições, o atelier } \\
\text { não fechará } \\
\text { 'Mesmo que haja poucas inscrições...' } \\
\text { - Sabendo que me é impossível tratar todas as } \\
\text { estruturas, vou no entanto referir algumas } \\
\text { propriedades } \\
\text { 'Embora saiba que me é impossível tratar todas } \\
\text { as estruturas...' }\end{array}$ \\
\hline Tempo (anterior ou simultâneo) & & $\begin{array}{l}\text { - Tendo as crianças adormecido, os pais foram } \\
\text { deitar-se } \\
\text { 'Depois de as crianças adormecerem..' } \\
\text { - Estando os meninos a dormir, o pai ouviu um } \\
\text { estrondo enorme } \\
\text { 'Quando os meninos estavam a dormir...' }\end{array}$ \\
\hline Condição & & $\begin{array}{l}\text { - Saindo de casa às oito e meia, conseguirás } \\
\text { chegar a horas } \\
\text { 'Se saires de casa às oito e meia...' } \\
\text { - Havendo poucas inscrições, o atelier fechará } \\
\text { 'Se houver poucas inscrições...' } \\
\text { - Ficando o Zé sentado ao teu lado, poderás } \\
\text { pedir-lhe ajuda } \\
\text { 'Se o Zé ficar sentado ao teu lado,...' }\end{array}$ \\
\hline Modo/Meio/Instrumento & $\begin{array}{l}\text { - Os ladrões arrombaram a porta usando um } \\
\text { martelo } \\
\text { 'Os ladrões arrombaram a porta com um } \\
\text { martelo' } \\
\text { - As andorinhas construíram os ninhos } \\
\text { juntando pequenos ramos } \\
\text { 'As andorinhas construíram os ninhos com } \\
\text { pequenos ramos' }\end{array}$ & \\
\hline Condição/Modo & $\begin{array}{l}\text { - Os atletas teriam melhores resultados } \\
\text { treinando mais horas por dia } \\
\text { '..., se treinassem mais horas por dia' } \\
\text { - O Zé teria menos dores ficando deitado } \\
\text { ‘..., se ficasse deitado.' }\end{array}$ & \\
\hline Tempo (simultâneo) & $\begin{array}{l}\text { - O Zé encontrou a solução para o problema } \\
\text { passeando pela cidade } \\
\text { ‘..., quando passeava pela cidade/ ..., ao } \\
\text { passear pela cidade' } \\
\text { - O Zé recebeu a notícia estando de férias nos } \\
\text { EUA } \\
\text { '..., quando estava de férias nos EUA.' }\end{array}$ & \\
\hline
\end{tabular}

Quadro1 - Valores semânticos das orações adjuntas - periféricas ou integradas. 
O quadro 2 abaixo mostra os testes sintáticos feitos tanto com orações gerundivas integradas quanto com as periféricas. As gerundivas integradas estabelecem uma relação mais estreita com a matriz e ocorrem de forma não marcada em posição final, podem ser clivadas, podem estar sob o escopo da negação matriz ou de advérbio de foco, podem constituir respostas a interrogativas-Qu, podem ocorrer em construções interrogativas e negativas alternativas e não admitem sujeitos plenos. Já as gerundivas periféricas ocupam tipicamente posição inicial, podem ter sujeito realizado ou não (sujeito pode ser um DP ou um pronome com caso nominativo).

\begin{tabular}{|c|c|c|}
\hline & Gerundivas integradas & Gerundivas periféricas \\
\hline Possibilidade de ser clivada & $\begin{array}{l}\text { a. Os ladrões conseguiram entrar arrombando a } \\
\text { porta com um maçarico } \\
\text { b.Foi arrombando a porta com um maçarico } \\
\text { que os ladrões conseguiram entrar } \\
\text { (OK) } \\
\text { (p.8, ex. (50a-b)) }\end{array}$ & $\begin{array}{l}\text { a. Estando doente, o Zé faltou à aula } \\
\text { b.*Foi estando doente que o Zé faltou à aula } \\
\text { (Não é possível) } \\
\text { (p.8, ex.(53a-b)) }\end{array}$ \\
\hline $\begin{array}{l}\text { Possibilidade de estar sob o escopo da } \\
\text { negação da matriz ou de advérbios de foco }\end{array}$ & $\begin{array}{l}\text { O Zé não ligou o aparelho seguindo as } \\
\text { instruções (Ligou-o de qualquer maneira) } \\
\text { (p.8, ex.(56a)) } \\
\text { (OK) }\end{array}$ & $\begin{array}{l}\text { Estando triste, o Zé não foi ao cinema (não é } \\
\text { possível obter a interpretação de que Zé foi ao } \\
\text { cinema, mas não por estar triste) } \\
\text { (Não é possível) ex.58) }\end{array}$ \\
\hline $\begin{array}{l}\text { Possibilidade de constitui resposta a } \\
\text { interrogativas -Qu }\end{array}$ & $\begin{array}{l}\text { - Como é que os ladrões entraram na casa? } \\
\text { - Arrombando a porta com um maçarico } \\
\text { (OK) }\end{array}$ & $\begin{array}{l}\text { - Por que é que Zé faltou à aula? } \\
\text { - *Estando doente } \\
\text { (Não é possível) }\end{array}$ \\
\hline $\begin{array}{l}\text { Possibilidade de ocorrer em construções } \\
\text { interrogativas e negativas alternativas }\end{array}$ & $\begin{array}{l}\text { Os ladrões arrombaram a porta batendo com } \\
\text { um martelo ou usando um maçarico? } \\
\text { (p.9, ex.66) }\end{array}$ & $\begin{array}{l}\text { *O Zé faltou à aula estando doente ou tendo } \\
\text { consulta? } \\
\text { (Não é possível) }\end{array}$ \\
\hline Posição & $\begin{array}{l}\text { Posição final ou inicial } \\
\text { - Os bombeiros deram o aviso tocando a sirene } \\
\text { - Tocando a sirene, os bombeiros deram o } \\
\text { aviso } \\
\text { (p.10, ex.75 e 77) }\end{array}$ & $\begin{array}{l}\text { Posição inicial } \\
\text { a. Estando com febre, Zé faltou a aula } \\
\text { b. *O Zé faltou à aula estando com febre } \\
\qquad(\text { p. } 9 \text {, ex.72) }\end{array}$ \\
\hline Sujeito & $\begin{array}{l}\text { Não admitem sujeitos plenos } \\
\text { a. O João não destruiu a carta queimando-a } \\
\text { b. *O João não destruiu a carta queimando-a o } \\
\text { Pedro } \\
\qquad \text { (p.11, ex.(87a-b)) }\end{array}$ & $\begin{array}{l}\text { Pode ter sujeito realizado ou não } \\
\text { - Estando o Pedro doente, a mãe teve de ficar } \\
\text { em casa } \\
\text { - Estando a chover torrencialmente, a mãe teve } \\
\text { de ficar em casa } \\
\text { (p.10, ex.81 e 82) }\end{array}$ \\
\hline $\begin{array}{l}\text { Interpretação causal (relação de } \\
\text { anterioridade em relação à principal) }\end{array}$ & Não é possível & $\begin{array}{l}\text { Tendo apanhado muito trânsito, o Zé chegou } \\
\text { atrasado } \\
\begin{array}{l}\text { É possível } \\
\text { (p.13, ex.106) }\end{array}\end{array}$ \\
\hline
\end{tabular}




\begin{tabular}{|c|c|c|}
\hline & Gerundivas integradas & Gerundivas periféricas \\
\hline $\begin{array}{l}\text { Valores concessivos, facilitados por } \\
\text { expressões adverbiais }\end{array}$ & Não é possível & $\begin{array}{l}\text { Mesmo tendo chegado atrasado, o Zé } \\
\text { conseguiu acompanhar a aula } \\
\text { É possível } \\
\text { Obs.: A concessão pode aparecer em } \\
\text { periféricas e integradas, no entanto a leitura de } \\
\text { tempo anterior só é possível em periféricas }\end{array}$ \\
\hline Gerúndio Composto & 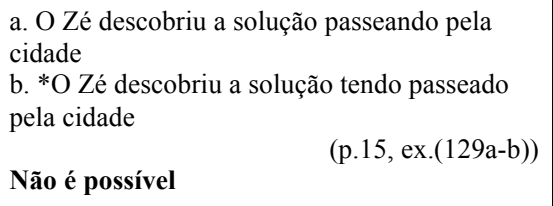 & $\begin{array}{l}\text { Tendo chegado atrasado, o Zé já não arranjou } \\
\text { lugar sentado } \\
\text { É possível }\end{array}$ \\
\hline $\begin{array}{l}\text { Especificações temporais distintas da oração } \\
\text { matriz }\end{array}$ & $\begin{array}{l}\text { *Os chimpanzés fizeram hoje os ninhos } \\
\text { juntando ontem os ramos } \\
\text { (Não é possível) }\end{array}$ & $\begin{array}{l}\text { Chegando a tua mãe amanhã, comecei hoje a } \\
\text { arranjar o quarto } \\
\text { (OK) }\end{array}$ \\
\hline
\end{tabular}

Em relação a essa distribuição, a autora afirma que:

$\mathrm{T}$ de gerundivas e participiais adjuntas é defectivo: quando c-comandado por $\mathrm{T}$ matriz, tem um comportamento anafórico, i.e. é obrigatoriamente interpretado como sendo temporalmente co-referente com T matriz, ou seja temporalmente simultâneo a/dependente de T matriz. (LOBO, 2003, p.20)

A proposta da autora é que o Tempo de gerundivas é defectivo, quando está no domínio de $\mathrm{T}$ da matriz fica ligado por este, dessa forma, só poderão ocorrer como orações adverbiais integradas as estruturas que possam ser interpretadas como temporalmente simultâneas a T matriz.. A autora afirma ainda (p.20):

O facto de o gerúndio ser morfologicamente defectivo, em conjunto com restrições de natureza semântica explica, assim, que as gerundivas de causa e de tempo anterior sejam obrigatoriamente projectadas para fora de TP, e tenham, consequentemente, comportamentos típicos de adverbiais periféricas.

Em orações infinitivas ou finitas não há dependência obrigatória de $\mathrm{T}$ matriz, isso ocorre possivelmente devido os conectores bloquearem a dependência de T matriz.

Em Lobo (2008, p.16) a autora defende que as gerundivas integradas e periféricas ocupam posições estruturais distintas. As gerundivas integradas ocupam posições relativamente mais baixas na estrutura, uma posição de adjunção a vP ou VP. Já as gerundivas periféricas ocupam posições mais altas na estrutura, estão adjuntas a categorias mais altas (CP ou IP). 
A autora, portanto, considera o Tempo das orações gerundivas adjuntas como defectivo, não totalmente especificado, e o núcleo da oração gerundiva contém traços fortes não interpretáveis que terão de ser verificados em T ou em C.

\subsubsection{Considerações parciais}

Lobo apresenta uma classificação para as orações gerundivas em português europeu. Tal classificação aparentemente não aborda diretamente as orações gerundivas com sujeito oracional. No entanto, em Lobo (2001a), a autora realiza testes com o sujeito das orações gerundivas de predicado (ou integradas) para mostrar que elas possuem maiores restrições sintáticas que as orações gerundivas de frase (ou periféricas). Um dos testes foi chamado pela autora de "sujeito sem antecedente" (Este museu foi recuperado aproveitando subsidios europeus), e, para ela, tal exemplo teria gramaticalidade duvidosa. A autora não realiza o mesmo teste para as gerundivas periféricas nesse trabalho, portanto fica uma dúvida em relação a possibilidade de uma sentença como essa ser possível em português europeu.

\subsection{Móia \& Viotti (2004): Descrição de interpretações semântica do gerúndio}

Móia \& Viotti (2004) apresentam questões em relação à semântica das orações gerundivas adverbiais e identificam os valores semânticos associados às orações gerundivas. Mostram, ainda, as restrições à distribuição desses valores. A hipótese dos autores sobre a semântica do morfema de gerúndio é a seguinte (p.720):

\footnotetext{
O gerúndio adverbial é um operador discursivo de associação de situações, i.e. é um conector interproposicional de 'amplo espectro', que requer que entre as situações associadas se estabeleça um de entre um leque possível de relações discursivas (a definir em função de factores contextuais e situacionais múltiplos), sendo por isso incompatível com eventos desconexos.
}

A partir dessa hipótese os autores apresentam os valores semânticos associáveis às gerundivas adverbiais e comentam algumas restrições em relação à sua distribuição. $\mathrm{O}$ quadro abaixo ilustra os valores semânticos associáveis às orações gerundivas adverbiais (Móia \& Viotti 2004, p.722 a 724): 


\begin{tabular}{|c|c|c|}
\hline & Características & Exemplos \\
\hline Gerúndio (narrativo) de posterioridade & $\begin{array}{l}\text { A oração gerundiva identifica uma situação } \\
\text { ocorrida depois da situando expressa na } \\
\text { oração matriz }\end{array}$ & $\begin{array}{l}\text { - A Ana saiu de casa a correr, dirigindo-se } \\
\text { apressadamente para o carro }\end{array}$ \\
\hline Gerúndio (narrativo) de anterioridade & $\begin{array}{l}\text { A oração gerundiva identifica uma situação } \\
\text { ocorrida antes da situação expressa na oração } \\
\text { matriz }\end{array}$ & $\begin{array}{l}\text { - Colocando bem o microfone, o orador } \\
\text { começou a falar } \\
\text { - Dizendo isto, calou-se }\end{array}$ \\
\hline $\begin{array}{l}\text { Gerúndio de sobreposição (ou paralelismo) } \\
\text { temporal }\end{array}$ & $\begin{array}{l}\text { A oração gerundiva identifica uma situação } \\
\text { concomitante com a situação expressa na } \\
\text { oração matriz }\end{array}$ & $\begin{array}{l}\text { - O poeta passeou pelo campo, pensando na } \\
\text { sua amada }\end{array}$ \\
\hline Gerúndio de sobreenquadramento & $\begin{array}{l}\text { A oração gerundiva identifica uma situação } \\
\text { (tipicamente atélica) que enquadra } \\
\text { temporalmente a situação expressa na oração } \\
\text { matriz. A gerundiva marca a situação } \\
\text { enquadradora }\end{array}$ & $\begin{array}{l}\text { - Estando eu na praia, aproximou-se de mim } \\
\text { um vendedor ambulante }\end{array}$ \\
\hline Gerúndio de subenquadramento & $\begin{array}{l}\text { A oração gerundiva identifica uma situação } \\
\text { que é enquadrada pela situação expressa na } \\
\text { oração matriz. A gerundiva marca a situação } \\
\text { enquadrada }\end{array}$ & $\begin{array}{l}\text { - A Ana esteve deitada na praia toda a tarde, } \\
\text { tendo visto passar vários iates de luxo }\end{array}$ \\
\hline Gerúndio de elaboração (ou mereológico) & $\begin{array}{l}\text { A oração gerundiva identifica uma } \\
\text { subsituação daquela situação expressa na } \\
\text { oração matriz }\end{array}$ & $\begin{array}{l}\text { - o Pedro renovou o jardim, tendo colocado } \\
\text { cercas de madeira em todos os canteiros } \\
\text { - A câmara construiu a ponte, tendo um } \\
\text { arquitecto francês desenhado os planos }\end{array}$ \\
\hline Gerúndio de modo & $\begin{array}{l}\text { A oração gerundiva identifica uma } \\
\text { característica da situaçnao que é expressa na } \\
\text { oração matriz }\end{array}$ & $\begin{array}{l}\text { - A Ana abraçou o Pedro, apertando-o } \\
\text { fortemente contra o peito }\end{array}$ \\
\hline Gerúndio instrumental (ou de meio) & $\begin{array}{l}\text { A oração gerundiva identifica o meio ou } \\
\text { instrumentopelo qual se chega à situação } \\
\text { expressa na oração matriz }\end{array}$ & $\begin{array}{l}\text { - O Paulo enriqueceu rapidamente } \\
\text { comprando e vendendo terrenos no Brasil }\end{array}$ \\
\hline Gerúndio causal & $\begin{array}{l}\text { A oração gerundiva identifica uma situação } \\
\text { que causa ou explica a situação que é expressa } \\
\text { pela oração matriz }\end{array}$ & $\begin{array}{l}\text { - Achando que a Ana gostava de flores, o } \\
\text { Paulo decidiu enviar-lhe um ramo de rosas }\end{array}$ \\
\hline Gerúndio resultativo & $\begin{array}{l}\text { A oração gerundiva identifica uma situação } \\
\text { que é consequência ou resultado da situação } \\
\text { expressa na oração matriz }\end{array}$ & $\begin{array}{l}\text { - O Paulo comprou e vendeu terrenos no } \\
\text { Brasil, enriquecendo rapidamente } \\
\text { - O Paulo achou que Ana gostava de flores, } \\
\text { tendo decidido enviar-lhe um ramo de } \\
\text { rosas }\end{array}$ \\
\hline Gerúndio condicional & $\begin{array}{l}\text { A oração gerundiva tem o valor de uma } \\
\text { oração condicional }\end{array}$ & $\begin{array}{l}\text { - Apertando este botão, a porta abre-se } \\
\text { - Não havendo atrasos, a mercadoria } \\
\text { chegará no dia } 2\end{array}$ \\
\hline Gerúndio concessivo ou adversativo & $\begin{array}{l}\text { A oração gerundiva em o valor de uma oração } \\
\text { concessiva ou adversativa }\end{array}$ & $\begin{array}{l}\text { - Estudando pouco, o Paulo consegue ter } \\
\text { boas notas } \\
\text { - O Paulo estuda pouco, conseguindo ter } \\
\text { boas notas }\end{array}$ \\
\hline Gerúndio apositivo & $\begin{array}{l}\text { A oração gerundiva identifica uma situação } \\
\text { que apenas contrasta com a situação expressa } \\
\text { na oração matriz }\end{array}$ & $\begin{array}{l}\text { - A Ana não foi para Londres, preferindo ir } \\
\text { para Paris }\end{array}$ \\
\hline Gerúndio neutro & $\begin{array}{l}\text { A orçando gerundiva identifica uma situação } \\
\text { que nem se relaciona temporalmente de modo } \\
\text { definido com a situação expressa na oração } \\
\text { matriz, nem envolve implicação ou contraste }\end{array}$ & $\begin{array}{l}\text { - A Índia está dividida em } 28 \text { estados e } 7 \\
\text { territórios, possuindo mais de mil milhões de } \\
\text { habitantes }\end{array}$ \\
\hline
\end{tabular}

Quadro 3: interpretações semântica das orações gerundivas adverbiais

O quadro apresenta uma análise descritiva das interpretações semânticas do gerúndio, não há proposta de estrutura. Tal quadro mostra como a descrição da gramática tradicional 
não leva em consideração várias sentenças possíveis, há possibilidades de interpretação semântica do gerúndio muito variadas, não há apenas orações adverbiais temporais, causais, concessivas e condicionais.

\subsubsection{Orações gerundivas com sujeito oracional}

Com relação às orações em que o sujeito da oração gerundiva não está coindexado ao sujeito da oração principal, os autores apresentam o exemplo de gerúndio adverbial resultativo em (90) (p.716, ex. (1e')). ${ }^{6}$

(90) A ana recitou bem o poema [recebendo muitos elogios]

A definição dada por Móia \& Viotti de gerúndio resultativo é (p.716):

Semanticamente, distinguem-se por envolverem uma combinação de duas proposições completas, que são relacionadas por um determinado valor semântico: (...) Resultado em (1 e') - [a Ana recitar bem o poema] [RESULTADO: a Ana receber muitos elogios].

Os autores abordam esse tipo de construção quando tratam dos valores semânticos associáveis às orações gerundivas adverbiais e um desses valores é o gerúndio resultativo, em momento algum eles afirmam que em tais estruturas a referência do verbo no gerúndio é toda a informação contida na oração principal (p.723):

A oração gerundiva identifica uma situação que é consequência ou resultado da situação expressa na oração principal, podendo ser o inverso de uma relação instrumental ou de uma relação causal. Estabelece-se uma Relação Discursiva de Resultado. Exemplo: o Paulo comprou e vendeu terrenos no Brasil, enriquecendo rapidamente; o Paulo achou que gostava de flores, tendo decidido enviar-lhe um ramo de rosas.

Os autores afirmam também que essas orações que marcam resultado só podem aparecer em posição final. Apesar de não analisarem a sintaxe de tal estrutura, pois seu trabalho é mais descritivo, os autores apresentam o gerúndio resultativo e tal exemplo assemelha-se às orações gerundivas com sujeito oracional, porém comporta-se de maneira um pouco diferente depois de uma análise mais detalhada (cf. Cap 3).

\footnotetext{
${ }^{6}$ Vale lembrar que os autores não têm como objetivo a descrição desse tipo de oração gerundivas com sujeito oracional, mas sim buscam mostrar os possíveis valores semânticos das orações gerundivas adverbiais.
} 


\subsubsection{Considerações parciais}

O trabalho realizado pelos autores é basicamente descritivo, mostram as possibilidades de interpretações semânticas para o gerúndio oracional. Para esta dissertação o foco é mostrar que Móia \& Viotti mostram diversos valores semânticos para as orações adverbiais gerundivas, enquanto na gramática tradicional há reduzidas de gerúndio temporais, causais, concessivas e condicionais.

Vimos que, com relação às orações gerundivas com sujeito oracional, os autores apresentam um dado que poderia ser um exemplo desse tipo de estrutura. Tal exemplo está incluído entre as orações gerundivas adverbiais e essa classificação será testada no próximo capítulo para identificar se tal dado é de fato um exemplo de oração gerundiva com sujeito oracional.

\subsection{Rodrigues (2007, 2010): Orações gerundivas em posição argumental}

\subsubsection{Rodrigues (2007): Orações gerundivas como complementos de verbos de percepção}

Rodrigues (2007, p.2. ex.4) tem o objetivo de analisar as orações gerundivas em estruturas com verbos de percepção, estrutura que também ocorre no inglês, como vemos em (91). A análise de Rodrigues mostra que, em inglês, há mais de uma interpretação, como mostrado em (91 b-d).

(91) a. I saw the moon rising over the mountain.

b. I saw the moon which was rising over the mountain.

c. I saw the moon as it was rising over the mountain.

$\mathrm{d}$. I saw the event of the moon's rising over the mountain.

Os exemplos $(91 b-d)$ são descrições das possíveis interpretações de (91a). O objetivo é mostrar que, em português, esse tipo de estrutura será dividida em duas possibilidades: (i) construções perceptivas concretas, que são ambíguas e comportam-se de forma similar ao inglês, tais construções possuem a característica de atribuir ao verbo de percepção a noção de visão, ou seja, ver no sentido de enxergar; (ii) construções perceptivas imaginativas não são ambíguas e possuem um única interpretação, a de constituinte único oracional (small clause), 
nesse caso o verbo de percepção possui o sentido interpretativo de imaginar, ou seja, ver no sentido de imaginar.

Vejamos primeiro a análise para o contexto concreto do verbo de percepção, existem três possíveis interpretações:

(i) O constituinte formando um DP complexo (p.31, ex.6):

(92) a. Você viu [DP o disco contendo canções de Natal], que tem a capa verde?

b. Você viu [DP a placa indicando saída, da qual a Maria falou?

Deve-se atentar para o fato de que, para a autora, neste caso o complemento gerundivo forma um DP complexo e não uma oração. O gerúndio pode modificar um nome e possui uma leitura atributiva.

(ii) Dois constituintes distintos: O DP que antecede o gerúndio é objeto do verbo de percepção, e o gerúndio, um adjunto predicativo (p.31, ex.8)

(93) a. Pedro viu o filme [comendo pipoca] (adjunto predicativo orientado para o sujeito)

b. João viu Pedro [correndo no parque] (adjunto predicativo orientado para o objeto)

(iii) Constituinte único oracional (small clause): nesses casos, o objeto de percepção não é o DP que antecede o gerúndio, mas sim o evento ou a situação denotada pelo complemento (p.32, ex.11,12 e 13)

(94) a. Eu vi [minhas ideias impondo-se com facilidade]

b. *Eu vi minhas ideias

(95) a.Eu vi [a bomba explodindo]

b. \# Eu vi a bomba

(96) a.Eu ouvi [a terra tremendo]

b. \# Eu ouvi a terra

Em seguida, a análise do contexto imaginativo para o verbo de percepção mostra que há apenas uma possível interpretação, a de constituinte único oracional.

(i) Constituinte único oracional (p.35, ex.19)

(97) O João viu (=imaginou) [o Pedro correndo no parque] 
A autora mostra com esses testes que, no português brasileiro ${ }^{7}$, as orações gerundivas em posição argumental são estruturas ambíguas. Com a leitura em contexto concreto (ver no sentido de enxergar) a sentença possui três interpretações: constituinte formando um DP complexo, dois constituintes distintos e constituinte único oracional (small clause). Já com a leitura em contexto imaginativo (ver no sentido de imaginar) há apenas uma interpretação, a de constituinte único oracional (small clause). Essa análise complementa o estudo de Moutella (1995) no sentido de que analisa mais profundamente as orações gerundivas em posição argumental, as quais, como dito por Moutella (1995), são inovações no português.

\subsubsection{Rodrigues (2010): orações gerundivas como complemento de verbos volitivos}

Rodrigues (2010) analisa as orações gerundivas como complementos de verbos volitivos. Assim como o trabalho de Rodrigues (2007), essas estruturas demonstram a existência de orações gerundivas que ocupam a posição de complemento do verbo da oração principal. A autora realiza os testes a serem a presentados a seguir para analisar esse tipo de estrutura que não é prevista nas descrições de gramáticas tradicionais.

- Teste 1: Clivagem. Verifica-se que só é possível clivar DP + Gerúndio, o que atesta que essa sequência forma um constituinte (p.3, ex.1,8 e 10)

(98) a. Os tucanos querem [o FHC falando das questões sociais].

b . Prefiro [a Volkswagen produzindo no Brasil].

(99) a. *É falando das questões sociais que os tucanos querem FHC

$\mathrm{b} *$ É produzindo no Brasil que prefiro a Volkswagen

(100) a. É FHC falando das questões sociais que os tucanos querem

b. É a Volkswagen produzindo no Brasil que eu prefiro

- Teste 2: Extração (p.3, ex.12 e 13).

(101) a. Os tucanos querem [FHC falando de questões sociais].

a'. De que os tucanos querem FHC falando?

(102) a. Eu encontrei [meus filhos estudando matemática]. a'. *O que eu encontrei meus filhos estudando?

\footnotetext{
${ }^{7}$ Vimos em Lobo (2001) que em português europeu também há orações gerundivas em posição argumental, que seria o uso predicativo do gerúndio
} 
O teste de extração mostra que (101), em que temos um verbo volitivo, funciona como argumento de querer, já o que temos em (102), a oração de gerúndio é adjunta a encontrar.

Os testes comprovam que as gerundivas testadas formam um constituinte único oracional, ou seja, uma small clause complemento. Os dois trabalhos de Rodrigues apontam dois contextos em que as orações gerundivas comportam-se como small-clauses (2007, p.30):

\begin{abstract}
Uma expressão que expressa uma relação predicado-sujeito, em que o predicado é composto por sintagma adjetival, um SN, um SP ou uma forma verbal não-finita que forma um constituinte único com seu sujeito.
\end{abstract}

\title{
2.4.3 Considerações parciais
}

Assim como Moutella (1995) e Lobo (2001), Rodrigues analisou a existência de orações gerundivas que ocupam a posição de argumento do verbo da oração principal. Tal estrutura foi considerada inovadora para Moutella, exatamente porque não é prevista pelas descrições tradicionais.

\subsection{Lopes (2004): Análise das orações apositivas de foco}

\subsubsection{As orações gerundivas adjetivas}

Lopes (2004) analisa as orações gerundivas relativas, inclui nelas as orações apositivas de foco, as quais serão analisadas com detalhamento aqui por serem uma classificação possível para as orações gerundivas com sujeito oracional.

A autora estuda o licenciamento do sujeito na oração adjetiva reduzida de gerúndio, a relação entre as propriedades semânticas do predicador e a distribuição da oração adjetiva de gerúndio em contextos de leitura progressiva e não-progressiva, ainda analisa a ocorrência da oração de gerúndio apositivas de foco.

Lopes defende o caráter predicativo do gerúndio dizendo (p.54): "Seu traço de aspecto [+Durativo] é compatível com as propriedades estativas, típicas do adjetivo. Em virtude disso, está o gerúndio capacitado para figurar como modificador de um nome”.

Lopes (2004) apresenta uma análise distinta de Moutella (1995) em relação às orações gerundivas adjetivas. Moutella considera as orações gerundivas relativas equivalentes a 
orações adjetivas restritivas. Já Lopes apresenta a possibilidade de estruturas reduzidas de gerúndio adjetivas restritivas ou explicativas respectivamente. (p.28, ex. 49 e 50):
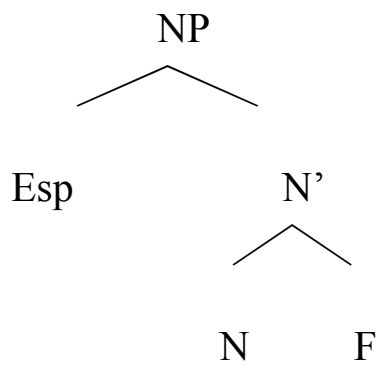

(106)
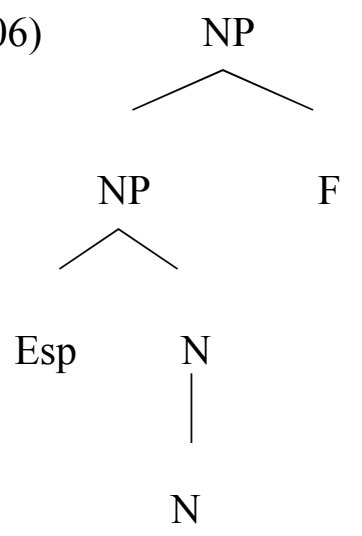

Em relação ao sujeito das reduzidas adjetivas, Lopes (2004) apresenta o estudo de Moutella (1995), em que ela considera o sujeito como um PRO coindexado a uma expressão nominal da matriz. A autora afirma que sob a perspectiva minimalista seria necessária uma outra explicação, mas afirma que esse não é objetivo dela no trabalho em questão.

\subsection{Orações gerundivas com sujeito oracional: as orações apositivas de foco}

A autora chama de apositivas de foco as orações gerundivas com sujeito oracional, as quais são analisadas nesta dissertação. Esse tipo de estrutura possui a característica de ter o sujeito da oração reduzida referente à situação descrita na matriz e não um elemento nominal dela, o sujeito do gerúndio seria um PRO de controle coindexado com a oração inteira, segundo a autora. Para demonstrar sua hipótese, faz o teste com a nominalização (p.69, ex. $(94 a-c)$ e (95a-c)):

(107) a. O avião caiu, deixando vários feridos. 
(108) a. [A queda do avião] deixou vários feridos.

(109) b. O clima está seco, causando desidratação.

(110) b. [A secura do clima] causa desidratação

(111) c. A qualidade de vida vem crescendo a cada dia, criando oportunidades para o povo brasileiro.

(112) c. [O crescimento da qualidade de vida] cria oportunidades para o povo brasileiro

A autora considera essencial o fato de essas estruturas terem de expressar uma leitura de causa/consequência, o que reflete na impossibilidade de mudança da posição. E essa impossibilidade de mudança de posição refuta a classificação de Moutella (1995) em aproximar essas estruturas às coordenadas. Orações coordenadas têm posição livre, portanto não seria possível classificar as orações apositivas de foco dessa maneira (p.69, ex.96):

(113) a. *Deixando vários feridos, o avião caiu

b. *Causando desidratação, o clima está seco

c. * Criando oportunidades para o povo brasileiro, a qualidade de vida vem crescendo a cada dia

Esse tipo de oração gerundiva é equivalente às orações relativas apositivas de foco, segundo Lopes, pois a oração subordinada constitui um comentário acerca da proposição anterior, essa equivalência é demonstrada pelos exemplos a seguir (p/70, ex.98):

(114) a. A justiça social já faz parte da vida dos brasileiros, o que proporciona/proporcionando melhor qualidade de vida, 0 que preserva/preservando os seus direitos de cidadãos.

b. Vivemos num mundo de terrorismos, drogas, medos, injustiças e corrupções, o que mostra/mostrando a insensatez e desorganização social e mundial.

Lopes classifica esses dados como exemplos de orações gerundivas apositivas de foco e tal classificação foi baseada em Mateus et al (2003).

Em Mateus et al (2003, p.671) as autoras afirmam que há, dentro da orações relativas explicativas (ou apositivas), as orações relativas apositivas de F, tais orações constituem um comentário acerca da proposição anterior. Porém, as autoras afirmam, na descrição das orações relativas explicativas, que os antecedentes possíveis para as orações relativas 
apositivas são: um nome próprio (Lisboa, que é a capital de Portugal, é uma cidade com uma luz especial), um pronome pessoal (Eu, que tanto me esforcei, cheguei em último lugar) e um SN com demonstrativos ou possessivos (Os teus primos, que vivem na califórnia, chegam hoje). Portanto as orações relativas apositivas de foco apresentadas parecem não poder ser incluídas nas orações relativas explicativas.

A classificação apresentada por Lopes (2004) não será seguida aqui, apesar de ser notável que as orações relativas apositivas de foco apresentadas em Mateus et al (2003) tenham característica parecida com o que ocorre nas orações gerundivas com sujeito oracional. Esse assunto será retomado no próximo capítulo.

\subsubsection{Considerações parciais}

O trabalho de Lopes analisa detalhadamente as orações relativas reduzidas, mostra que a referência do verbo no gerúndio da oração reduzida deve ser um elemento nominal da oração principal, assim como vimos em Moutella (1995). Também vimos que é importante encontrar uma explicação melhor para o funcionamento do sujeito nesse tipo de oração, pois a explicação de Controle por PRO coindexado não seria suficiente segundo Lopes.

A autora apresenta testes pertinentes para analisar as orações gerundivas com sujeito oracional, tais testes serão aqui realizados. A classificação dada por Lopes às orações gerundivas com sujeito oracional demonstra uma preocupação em explicar o funcionamento desse tipo de oração, em que há uma retomada do que se referiu na oração principal. 


\section{CAPÍTULO 3: Análise das orações gerundivas com sujeito oracional}

\subsection{Nota Introdutória}

Neste capítulo será feita a análise das orações gerundivas com sujeito oracional. Para isso serão feitos testes baseados nos estudos apresentados no capítulo anterior. Dessa forma identificaremos se alguma classificação compreende as orações gerundivas com sujeito oracional.

\subsection{Análise para as orações gerundivas com sujeito oracional}

Ao investigar as classificações atribuídas às orações gerundivas como as em (1), repetidas abaixo como (115), constatou-se que tais orações têm recebido pelo menos três possíveis classificações: (i) Orações Coordenadas, segundo Moutella (1995); (ii) Orações adverbiais com gerúndio resultativo, segundo Móia \& Viotti (2004) e (iii) Apositivas de foco, segundo Lopes (2004).

(115) a. Segundo a lei, nos últimos dois anos o índice foi reduzido para zero, tornando a lei mais eficaz, desta forma a proporção de acidentes está cada vez menor.

b. O estado interviu na forma de conscientizar as pessoas por meio de uma lei rigorosa, assim caminhando para um país desenvolvido com segurança e acima de tudo respeito.

c. A participação de todos é indispensável nessa luta contra as infrações, reduzindo assim as lamentações dos familiares de vítimas de álcool.

d. A conscientização da população só veio com a diminuição do número de mortes em acidentes de trânsito, mostrando os efeitos positivos dessa lei.

Tanto Moutella (1995) quanto Lopes (2004) afirmam que esse tipo de estrutura possui a característica de ter o sujeito da oração subordinada co-referencial a toda a informação contida na matriz e não apenas ao sujeito ou ao objeto da oração principal. Moutella (1995) compara a oração em (116a) com (116b). Para ela, as orações gerundivas com sujeito oracional assemelham-se à orações coordenadas. 
(116) a. O avião caiu, matando 150 pessoas

b. Avião cai e mata 150 pessoas

Lopes (2004), por sua vez, compara a oração gerundiva com sujeito oracional em (117a) à (117b). Para ela, a correspondente das orações gerundivas com sujeito oracional é uma oração relativa "apositiva de foco".

(117) a. O avião caiu, matando 150 pessoas

b. O avião caiu, o que matou 150 pessoas

Lopes também considera essencial o fato de essas estruturas terem de expressar uma leitura de causa/consequência. Essa relação faz com que não seja possível a mudança da posição da oração apositiva de foco. Esse é o argumento usado pela autora para defender a ideia de que tais orações não seriam orações coordenadas, como propôs Moutella (1995). Como se pode atestar abaixo, as orações "apositivas de foco" não podem mudar sua posição (p.69, ex.96):

(118) a. *Deixando vários feridos, o avião caiu.

b. *Causando desidratação, o clima está seco.

c. *Criando oportunidades para o povo brasileiro, a qualidade de vida vem crescendo a cada dia.

Lopes apresenta um outro teste, a favor de sua análise, que é o teste de nominalização, para mostrar a leitura de a causa/consequência das orações relativas apositivas de foco. As orações apositivas de foco, como (119a), podem ser nominalizadas como o comprovado em (119b) (Lopes 2004, p.69, ex. (94a) e (95a)):

(119) a. O avião caiu deixando vários feridos.

b. [A queda do avião] deixou vários feridos.

Móia \& Viotti (2004), ao fazerem um estudo sobre a semântica das gerundivas adverbiais, também incluem, mesmo que sem intenção orações gerundivas em que o sujeito da oração gerundiva está ligada ao sentido de toda a oração principal. Os autores apresentam o exemplo para orações reduzidas de gerúndio e afirmam que tais orações incluem uma semântica de resultado (p.716, ex. (1e')):

(120) A Ana recitou bem o poema [recebendo muitos elogios] 
Percebe-se que tal estrutura assemelha-se às apositivas de foco apresentadas por Lopes (2004), porém tais estruturas não podem ser classificadas como orações relativas apositivas de foco, pois ao fazermos o teste da nominalização, vemos que a oração (121a) não é gramatical. Já ao se fazer o teste de nominalização, proposto por Lopes em (121b), vê-se que a sentença é gramatical. O teste da mudança de posição em (121c) produz sentença agramatical como esperado por Lopes.

(121) a. *A Ana recitou bem o poema, o que recebeu muito elogios.

b. O recital de Ana recebeu muitos elogios.

c. *Recebendo muitos elogios, a Ana recitou bem o poema.

Apesar de dois dos testes apresentarem resultados esperados por Lopes para classificar tal dado como exemplo de oração gerundiva relativa apositiva de foco, o testes em (121a) mostra que o apresentado por Móia \& Viotti (2004) não se comporta da mesma maneira que as demais orações gerundivas com sujeito oracional ${ }^{8}$, pois não são equivalente a oração relativa.

Por fim, como se pôde verificar, o quadro teórico sobre orações reduzidas de gerúndio não é uniforme e há problemas em classificar as gerundivas aqui analisadas. As orações gerundivas com sujeito oracional possuem características específicas e devem ser analisadas detalhadamente. A partir dos estudos analisados tentaremos estabelecer uma forma mais objetiva de análise que aborde essas estruturas.

\subsection{Análise dos dados - classificação das orações gerundivas com sujeito oracional}

Analisaremos agora as orações em (1), renumeradas como (122), mais detalhadamente. Para tanto faremos testes baseados nos estudos dos autores aqui analisados.

(122) a. Segundo a lei, nos últimos dois anos o índice foi reduzido para zero, tornando a lei mais eficaz, desta forma a proporção de acidentes está cada vez menor.

b. O estado interviu na forma de conscientizar as pessoas por meio de uma lei rigorosa, assim caminhando para um país desenvolvido com segurança e acima de tudo respeito.

\footnotetext{
${ }^{8}$ Porém, se fizermos o testes com o dado: A Ana recitou bem o poema, tirando aplausos da plateia. Vemos que a equivalência à oração relativa funciona: A Ana recitou bem o poema, o que tirou aplausos da plateia. Portanto, há ainda muito o que investigar no que diz respeito às orações gerundivas com sujeito oracional em português europeu.
} 
c. A participação de todos é indispensável nessa luta contra as infrações, reduzindo assim as lamentações dos familiares de vítimas de álcool.

d. A conscientização da população só veio com a diminuição do número de mortes em acidentes de trânsito, mostrando os efeitos positivos dessa lei.

e. Começou a gargalhar chamando a atenção dos outros feirantes

\subsubsection{Utilizando testes e análises de Lobo}

Lobo apresenta as orações gerundivas adjuntas e as classifica como periféricas e integradas, o objetivo é saber se as orações gerundivas com sujeito oracional podem ser classificadas de uma dessas maneiras. Três de seus testes serão usados aqui para verificar se as orações em (122) fazem parte de algum desses dois grupos (periféricas e integradas).

Teste 1 - Posição: a autora afirma que gerundivas integradas possuem a opção de estarem em posição final ou inicial, já as gerundivas periféricas só podem estar na posição inicial. As orações em (123) são claramente problemáticas.

(123) a.*Tornando a lei mais eficaz, nos últimos anos o índice foi reduzido para zero.

b. *aminhando para um país desenvolvido, o estado interviu na forma de conscientizar as pessoas por meio de uma lei rigorosa.

c.*Reduzindo assim as lamentações dos familiares de vítimas de álcool, a participação de todos é indispensável nessa luta contra as infrações.

d. *Mostrando os efeitos positivos da lei, a conscientização da população só veio com a diminuição do número de mortes em acidentes de trânsito.

e.*Chamando a atenção dos outros feirantes, começou a gargalhar

Esse primeiro teste não permite que essas orações sejam consideradas gerundivas periféricas, pois não há exigência de estarem em posição inicial e também não as coloca dentro das gerundivas integradas porque sua posição não é livre.

Teste 2 - Possibilidade de ser clivada: As gerundivas integradas podem ser clivadas e as gerundivas periféricas não podem.

(124) a. *Foi tornando a lei mais eficaz que nos últimos dois anos o índice foi reduzido para zero.

b. *Foi assim caminhando para um país desenvolvido com segurança e acima de tudo respeito que o estado interviu na forma de conscientizar as pessoas por meio de uma lei rigorosa.

c. *Foi reduzindo assim as lamentações dos familiares de vítimas de álcool.que a participação de todos é indispensável nessa luta contra as infrações. 
d. *Foi mostrando os efeitos positivos dessa lei que a conscientização da população só veio com a diminuição do número de mortes em acidentes de trânsito.

e. ?Foi chamando a atenção dos outros feirantes que começou a gargalhar.

O resultado visto em (124) mostra que tais orações não podem ser classificadas com orações gerundivas integradas.

Teste 3 - Gerúndio composto: não é possível em gerundivas integradas e é possível em gerundivas periféricas.

(125) a. Segundo a lei, nos últimos dois anos o índice foi reduzido para zero, tendo tornado a lei mais eficaz, desta forma a proporção de acidentes está cada vez menor.

b. O estado interviu na forma de conscientizar as pessoas por meio de uma lei rigorosa, assim tendo caminhado para um país desenvolvido com segurança e acima de tudo respeito.

c. A participação de todos é indispensável nessa luta contra as infrações, tendo reduzido assim as lamentações dos familiares de vítimas de álcool.

d. A conscientização da população só veio com a diminuição do número de mortes em acidentes de trânsito, tendo mostrado os efeitos positivos dessa lei.

e. ?Começou a gargalhar tendo chamado a atenção dos outros feirantes

O resultado visto em (125) demonstra que a passagem pra gerúndio composto é possível com as orações gerundivas com sujeito oracional, porém parece que a interpretação de causa e consequência deixa de existir, mesmo que sejam orações gramaticais. A gramaticalidade classificaria as orações em (1) em orações gerundivas periféricas.

As orações gerundivas com sujeito oracional não podem ser incluídas totalmente em gerundivas periféricas ou gerundivas integradas. Principalmente devido o testes da mudança de posição.

Aparentemente as orações gerundivas com sujeito oracional comportam-se de forma tal que, pelo menos por enquanto, não há como saber se tais dados ocorrem em português europeu.

\subsubsection{Utilizando análise de Moutella (1995)}

Sobre as orações gerundivas com sujeito oracional, Moutella (1995) afirma que seriam comparáveis a orações coordenadas (Avião cai e mata 150 pessoas), a seguir encontram-se os testes para identificar se a equivalência entre as orações gerundivas com sujeito oracional e as orações coordenadas é possível. 
(126) a. Segundo a lei, nos últimos dois anos, o índice foi reduzido para zero, e tornou a lei mais eficaz, desta forma a proporção de acidentes está cada vez menor.

b. ? O estado interviu na forma de conscientizar as pessoas por meio de uma lei rigorosa, e assim caminha para um país desenvolvido com segurança e acima de tudo respeito.

c. A participação de todos é indispensável nessa luta contra as infrações e reduz assim as lamentações dos familiares de vítimas de álcool.

d. ?A conscientização da população só veio com a diminuição do número de mortes em acidentes de trânsito e mostra os efeitos positivos dessa lei.

e. Começou a gargalhar e chamou a atenção dos outros feirantes

O teste em (126) mostra uma aceitabilidade da transformação das orações gerundivas com sujeito oracional em orações coordenadas. Porém Lopes (2008) refuta essa classificação, pois a mudança de posição das orações gerundivas com sujeito oracional não é possível e isso demonstra que classificá-las como orações coordenadas é problemáticos, pois as orações coordenadas são livres para troca de posição. Lopes (2004) testa a mudança de posição da orações gerundivas "apositivas de foco", como em (123).

Foi comprovada a impossibilidade de mudança de posição dessas construções chamadas de apositivas de foco por Lopes, o que comprova que tais orações não são equivalentes às orações coordenadas.

\subsubsection{Utilizando testes de Lopes}

Lopes (2004) afirma que as orações gerundivas com sujeito oracional são orações relativas reduzidas do tipo apositivas de foco. Seriam, portanto, equivalentes a orações relativas apositivas de foco. A autora utiliza dois testes para argumentar a favor de sua hipótese: a equivalência a relativas e a nominalização.

Teste1 - Equivalência a relativas

(127) a. Segundo a lei, nos últimos dois anos o índice foi reduzido para zero, o que torna a lei mais eficaz, desta forma a proporção de acidentes está cada vez menor.

b. ?O estado interviu na forma de conscientizar as pessoas por meio de uma lei rigorosa, o que caminha assim para um país desenvolvido com segurança e acima de tudo respeito.

c. A participação de todos é indispensável nessa luta contra as infrações, o que reduz assim as lamentações dos familiares de vítimas de álcool.

d. A conscientização da população só veio com a diminuição do número de mortes em acidentes de trânsito, o que mostra os efeitos positivos dessa lei.

e. Começou a gargalhar, o que chamou a atenção dos outros feirantes 
O teste em (127) mostra que essa equivalência é quase sempre possível, portanto as orações gerundivas com sujeito oracional são equivalentes a orações relativas.

Teste 2 - Nominalização da oração principal: há um problema em realizar este teste, pois alguns dos dados já estão nominalizados, mostro abaixo somente os testes para os dados que não estavam já nominalizados originalmente:

(128) a. A redução do índice para zero, tornou a lei mais eficaz.

b. ?A intervenção do estado na forma de conscientizar as pessoas por meio de uma lei rigorosa, caminha para um país desenvolvido com segurança e acima de tudo respeito.

e. O começar a gargalhar chamou a atenção dos outros feirantes

O testes de nominalização é feito para confirmar a hipótese da autora de que o sujeito do gerúndio é um PRO de controle coindexado com a oração inteira e corrobora a leitura de causa/consequência da sentença. O resultado da nominalização em (128b) mostra que em determinados momentos as orações gerundivas com sujeito oracional encontradas nos dados do ENEM foram aplicados em contextos diferentes dos esperados por Lopes (2004), mas será necessária uma análise futura sobre isso.

\subsection{Proposta de análise}

Inicialmente vimos que haveria pelo menos três possíveis classificações para as orações gerundivas com sujeito oracional em (122): (i) orações coordenadas, segundo Moutella (1995); (ii) orações adverbiais com gerúndio resultativo, segundo Móia \& Viotti (2004) e (iii) orações apositivas de foco, segundo Lopes (2004).

Ao realizar os testes, vimos que as orações gerundivas com sujeito oracional podem ser correlatas às orações coordenadas, porém Lopes (2004) refuta essa classificação. Mostra que as orações apositivas não podem mudar de posição, se fossem coordenadas isso deveria ser possível. A análise de Castilho (2010), em relação às orações coordenadas, corrobora o que foi dito por Lopes (2004), pois o autor mostra que as orações coordenadas são simétricas, ou seja, os elementos coordenados podem mudar de posição no enunciado sem alternância de interpretação semântica. Dessa forma, as orações gerundivas com sujeito oracional não poderiam ser classificadas como orações coordenadas, porém parece que para eliminar a 
semelhança das orações gerundivas com sujeito oracional com as orações coordenadas seria necessário mais pesquisa e mais testes.

Móia \& Viotti (2004) não apresentam testes para as gerundivas com gerúndio resultativo, mas já havíamos mostrado que o exemplo mostrado pelos autores não segue exatamente o que estamos considerando como orações gerundivas com sujeito oracional, pois são os únicos exemplos que não podem ser transformados em relativas (cf. 3.1), porém ainda é necessário um estudo sobre esse dado, pois a mudança do verbo no gerúndio pode alterar a análise do testes.

Os testes propostos por Lopes (2004) parecem ser os mais adequados. De fato, as orações gerundivas com sujeito oracional podem ser classificadas como orações relativas, porém classificá-las em orações relativas apositivas de foco, um subgrupo das orações relativas explicativas, não parece adequado. Tanto nas gramáticas tradicionais, quanto nos estudos de Moutella (1995) e Lopes (2004), há consenso em considerarem que a principal propriedade das orações relativas é o fato de a oração subordinada relativa modifica algum termo da oração principal. Portanto as orações gerundivas com sujeito oracional devem ser classificadas de outra forma, ou deve-se ampliar as possibilidades de sujeito desses tipos de orações. As orações gerundivas com sujeito modificam toda a informação contida na oração principal, nesse sentido, não estão relacionadas a um termo nominal específico da oração principal. Comportam-se, de fato, de uma forma diferente das demais orações gerundivas, por isso necessitam de uma classificação diferente.

Para comprovar esse comportamento das orações relativas sempre modificarem um elemento da oração principal, vejamos em Mateus et al (2003) a natureza do antecedente de orações relativas explicativas e apositivas (=restritivas).

As autoras afirmam em Mateus et al (p.668, ex. de 46-50) que as orações relativas restritivas podem ter como antecedente diversos tipos de determinantes/quantificadores $+\mathrm{N}$, além desses casos temos o mostrado em (129). O exemplo em (129a) mostra o antecedente como um N sem D explícito; em (129b) temos o antecedente como uma expressão nominal quantificada e (129c) o antecedente é uma expressão nominal demonstrativa; e, por fim, em $(129 \mathrm{~d}$, e) temos um exemplo do antecedente das orações relativas restritivas como determinantes não seguidos de $\mathrm{N}$ (ou "pronomes demonstrativos):

(129) a. Dinheiro que eu ganhe fica logo gasto

b. Tudo quanto aconteceu me abalou

c. Aquilo que me disseste é assustador 


\section{d. Os que escreveram são meus amigos \\ e. Aqueles que escreveram são meus amigos}

Em Mateus et al (p.671, ex. 1-4) vemos que as orações relativas apositivas ou explicativas podem ter como antecedente o mostrado em (130). O exemplo em (130a) mostra o antecedente da oração relativa apositiva como um $\mathrm{N}$ próprio; em (130b) temos o antecedente como um pronome pessoal; e em (130c) o antecedente é um SN com demonstrativos ou possessivos:

(130) a. Lisboa , que é a capital de Portugal, é uma cidade com uma luz especial.

b. Eu, que tanto me esforcei, cheguei em último lugar.

c. Os teus primos, que vivem na Califórnia, chegam hoje.

Como visto acima, em Mateus et al (2003) identifica-se as possibilidade de antecedentes para as orações explicativas e, em todos os casos, a referência do verbo da oração explicativa é um elemento nominal da oração principal.

O que podemos dizer com certeza sobre as orações gerundivas aqui analisadas é que elas possuem as seguintes características sintáticas: (i) o sujeito da oração gerundivas é toda a informação contida na oração principal; (ii) há necessidade de ocorrerem na segunda posição dentro da sentença, ou seja, a mudança de posição não é possível; (iii) podem ser transformadas em orações relativas iniciadas por "o que". Esse último fato permite que passemos a levar em consideração a possibilidade das orações gerundivas com sujeito oracional se comportarem de forma parecida com as orações relativas livres ou semilivres.

Móia (1992) explica que as orações relativas livres têm como característica o fato de que a oração relativa não está associada a um antecedente nominal realizado. Ou seja, segundo o autor, as orações relativas são orações em que o pronome relativo possui um referente expresso na oração anterior (oração principal). Já as orações relativas livres não se referem a um elemento específico da oração anterior.

Por isso, o autor passa a classificar as orações relativas em orações relativas com antecedente (orações relativas adjetivas e explicativas) e orações relativas sem antecedente (que são as orações conhecidas na literatura como relativas livres). Para entender a diferença entre relativas com antecedente e as relativas sem antecedente expresso (livres), vejamos os exemplos apresentados pelo autor (Móia, 1992, p.1, ex.1 e 2): 
(130) a. Quem conhece o Luís sabe que ele é um rapaz sensato.

b. As pessoas que conhecem o Luís sabem que ele é um rapaz sensato.

Em (130a) temos uma oração relativa sem antecedente, ou seja, não há qualquer antecedente nominal realizado associado à oração relativa. Já em (130b) existe o antecedente As pessoas.

Com relação à análise estrutural desse tipo de estrutura de relativas livres, Móia defende a hipótese de que existe um antecedente nulo. Sendo assim, a oração relativa seria um SCOMP encaixado num SN, que tem por núcleo uma categoria vazia, como ocorre em (131) abaixo (Móia, 1992, p.3, ex.7):

(131) O professor $\left[_{\mathrm{SV}}[\mathrm{V}\right.$ elogiou $]\left[_{\mathrm{SN}}[]\left[_{\mathrm{SCOMP}}\right.\right.$ quem leu o livro $\left.\left.]\right]\right]$

O símbolo [] no SN representa o elemento nulo de tipo não especificado. Portanto existe um antecedente nominal na estrutura, porém ele não é realizado lexicalmente.

As orações sem antecedente expresso comportam-se de forma diferente das orações relativas com antecedente expresso no que diz respeito às restrições relacionadas aos morfemas que podem surgir e aos requisitos de conformidade a que elas estão sujeitas.

As orações sem antecedente podem ser encabeçadas por quem, o que, quanto, onde, como e quando. Como as orações gerundivas com sujeito oracional são equivalentes a orações relativas encabeçadas por "o que”, devemos ressaltar que o autor afirma que tal morfema tem traço [- Humano] e considera "o que" como um morfema relativo e não, como por vezes é sugerido, uma sequência artigo e demonstrativo.

$\mathrm{O}$ autor distingue as ocorrências de o que, sendo que o caso a ser estudado é a ocorrência de $o$ que como morfema relativo. Vejamos a diferença de ocorrência (Móia, 1992, p.10, ex.21 e 22):

(132) Este livro não é meu. O que te emprestei tinha a capa vermelha.

(133) Deves devolver-me o que te emprestei.

Em (132) temos uma oração relativa com antecedente expresso, introduzida por "que" e o artigo masculino singular antecedente não faz parte do morfema relativo, e "o que”, nesse caso, é variável, como atestado em (134) abaixo. Já o exemplo em (133) apresenta uma forma invariável de "o que”, que pode ocorrer, nesse caso, no mesmo contexto 
que o demonstrativo aquilo, como mostrado em (135), e é nesse caso que temos um exemplo de relativa sem antecedente expresso (Móia, 1992, p.11, ex. 24 e 26):

(134) Estes livros não são meus. Os que te emprestei tinham a capa vermelha.

(135) Deves devolver-me aquilo que eu te emprestei.

O autor, a partir do que foi dito acima, considera que as orações relativas sem antecedente expresso são introduzidas pelo morfema relativo "o que”, e mostra que tais orações possuem as mesmas propriedades distribucionais que a orações relativas sem antecedente expresso introduzidas por outros morfemas.

Em um teste preliminar, submetemos as orações gerundivas com sujeito oracional, já transformadas em orações relativas, ao teste proposto por Móia (1995), como mostrado em (136):

(136) a. O índice foi reduzido para zero, o que tornou a lei mais eficaz

a'. Os índices foram reduzidos para zero, *os que/ isso tornou a lei mais eficaz

b. O estado interviu na forma de conscientizar as pessoas por meio de uma lei rigorosa, o que caminha para um país desenvolvido

b'. O estado interviu na forma de conscientizar as pessoas por meio de leis rigorosas, *os que/ isso caminha para um país desenvolvido

c. A conscientização da população só veio com a diminuição do número de mortes em acidentes de trânsito, o que mostra os efeitos positivos dessa lei.

c'. As conscientizações das populações só vieram com a diminuição do número de mortes em acidentes, *os que/ isso mostra os efeitos positivos dessa lei.

e. Começou a gargalhar *os que/ isso chamou a atenção dos outros feirantes

O teste em (136) mostra que, preliminarmente, podemos classificar as orações gerundivas com sujeito oracional em orações relativas livres. Pois o que nesse casso é invariável, ou seja, é um morfema relativo e não uma sequência de artigo $o$ mais pronome relativo que.

Será necessária uma análise mais detalhada no que diz respeito à consideração das orações gerundivas com sujeito oracional como equivalentes à orações relativas livres. Mas o fato é que a hipótese por enquanto pode ser seguida e serão feitos mais testes em trabalho futuro. 
Esta dissertação investigou as propriedades sintáticas e semânticas de orações reduzidas de gerúndio em que o referente do verbo no gerúndio é toda a informação contida na oração principal. Dois fatores principais motivaram a realização da pesquisa: a) não há descrições nas gramáticas tradicionais brasileiras sobre a existência de orações gerundivas com sujeito oracional; b) não há consenso nas análises de cunho gerativistas que investigaram o tema. A hipótese defendida foi a de que as orações gerundivas reduzidas de gerúndio com sujeito oracional são orações cujas características sintáticas e semânticas são comparáveis às de orações relativas livres (cf. Moia 1992), iniciadas por o que.

As características das orações gerundivas com sujeito oracional, identificadas aqui, foram: (i) o sujeito de tais orações reduzidas não é um elemento nominal da oração principal, mas sim toda a informação contida nela; (ii) ocorrem em posição final, pois mudança de posição não é possível e (iii) são substituíveis por relativas iniciadas por "o que" sistematicamente.

Conjuntamente com a análise das orações gerundivas com sujeito oracional, vimos como o quadro teórico sobre orações gerundivas em geral, dentro da teoria gerativa, não é muito vasto e as perspectivas são diferentes, o que nos leva a perceber uma falta de consenso. Dessa forma, esta dissertação contribuiu para um apanhado objetivo e conveniente para estudos futuros relacionados a essas estruturas. Nesse sentido, a hipótese das orações gerundivas com sujeito serem semelhantes a orações relativas livres será aprofundada e testada detalhadamente.

Vimos que, na descrição da gramática tradicional, não figuram as orações gerundivas com sujeito oracional, e se os alunos em fase final do ensino médio produzem tais construções é basilar estudar detalhadamente as motivações e o funcionamento desses dados.

Esta dissertação integra um primeiro passo para propor uma estrutura adequada às orações gerundivas com sujeito oracional. Nesse sentido, as questões em aberto são as seguintes: (i) Como comprovar se as orações gerundivas com sujeito oracional são um tipo de orações relativas livres?; (ii) Como podemos explicar o comportamento do sujeito nessas orações? Afinal, vimos que o sujeito de orações gerundivas é sempre um elemento nominal 
específico da oração principal e as orações com sujeito oracional não comporta-se dessa forma; (iii) Há semelhanças entre português e inglês no que diz respeito à orações gerundiva? O interesse em investigar as orações gerundivas em inglês surge com o objetivo de saber se nesta língua há orações gerundivas com sujeito oracional, e será importante fazer essa investigações em outras línguas também; E (iv) Quais são as diferenças entre as orações gerundivas do PB e do PE? Como explicá-las? Será necessário investigar se ocorre em PE exemplos de orações gerundivas com sujeito oracional, pois essa foi um dúvida surgida no decorrer desta dissertação. 
CASTILHO, Ataliba T. Nova gramática do português brasileiro. Editora Contexto. São Paulo, 2010.

CHOMSKY, Noam. Arquitetura da linguagem. EDUSC. São Paulo, 2008.

CUNHA, Celso \& CINTRA, Lindley. Nova gramática do português contemporâneo. Lexikon Editora Digital. Rio de Janeiro, 2008.

FERREIRA, Sílvia Aguiar. Sobre a função e a forma de alguns subtipos especiais de orações relativas sem antecedente expresso do português. Dissertação de mestrado, Universidade de Lisboa. Lisboa, 2007.

HORNSTEIN, N., NUNES, J., GROHMANN, K. Understanding minimalismo. Cambridge University Press. New York, 2005.

LOBO, Maria. Aspectos da Sintaxe das Orações Gerundivas Adjuntas no Português. Actas do $17^{\circ}$ Encontro Nacional da Associação Portuguesa de Linguística. Lisboa, 2001a. Aspectos da sintaxe das orações subordinadas adverbiais do português. Dissertação de doutorado. Universidade Nova de Lisboa. Lisboa, 2001b Orações adverbiais com conectores vs. orações adverbiais sem conectores: distribuição e propriedades sintáticas. Universidade do Minho. Lisboa, 2003.

Dependências temporais: a sintaxe das orações subordinadas gerundivas do português. Veredas Portugal. Lisboa, 2008.

LOPES, Josmária Madalena. Orações Gerundivas adjetivas no português do Brasil. Dissertação de mestrado. Universidade de Brasília - UnB. Brasília, 2004.

MATEUS, Mira et. al. Gramática da língua portuguesa. Editorial Caminho, SA. Lisboa, 2003.

MÓIA, Telmo. A sintaxe das orações relativas sem antecedente expresso do português. Dissertação de mestrado, Universidade de Lisboa. Lisboa, 1992.

MÓIA, Telmo \& VIOTTI, Evani. Sobre a semântica das orações gerundivas adverbiais. Actas do XX Encontro Nacional da Associação Portuguesa de Linguística. Lisboa, 2004 
MOUTELlA, Emília Manuela R. O gerúndio oracional em português. Dissertação de mestrado. Universidade de Brasília - UnB. Brasília, 1995.

NETO, J. Ferrari \& SILVA, C. R. Tavares (org.). Programa minimalista em foco: princípios e debates. Editora CRV. Curitiba, 2012

PIRES, Acrisio. Clausal and TP-Defective Gerunds: Control Without Tense. NELS 31, University of Maryland at College Park. Maryland, 2001.

The Minimalist Syntax of Defective Domains: gerunds and infinitives. University of Michigan, Ann Arbor. John Benjamins Publishing Company Amsterdam/Philadelphia. Philadelphia, 2006. 